\title{
Los baptisterios parroquiales de Jerez de la Frontera en la Edad Moderna. Una propuesta metodológica para estudios de liturgia y arquitectura
}

\author{
The parish baptisteries in Jerez de la Frontera \\ in the Modern Age. A methodological proposal for \\ studies of liturgy and architecture
}

Pablo J. POMAR RODIL

Universidad de Sevilla

Recibido: 21-IV-2017

Aceptado: 25-V-2017

RESUMEN: Las capillas del bautismo de la Colegiata de San Salvador y demás parroquias de Jerez de la Frontera presentan como conjunto un interés histórico artístico considerable y algunas en concreto son además, bien sea por su singularidad tipológica o por su entidad arquitectónica y decorativa, ejemplares notables. Sin embargo, será volcando el caudal de noticias referidas a la historia constructiva de estos baptisterios parroquiales en un estudio de mayor amplitud sobre su funcionalidad litúrgica -tomando como principales referencias el Ritual Romano y las Constituciones Sinodales hispalenses- donde el mencionado conjunto de capillas se revele como muestra suficiente de la cual extraer conclusiones aplicables tanto al resto de parroquias de la Archidiócesis de Sevilla, como a otras del ámbito hispano durante la Edad Moderna.

Palabras clave: Baptisterio, Arquitectura, Liturgia, Parroquia, Jerez de la Frontera, Pila bautismal, Rejería, Ritual Romano.

ABSTRACT: The baptismal chapels in the Cathedral of San Salvador and the rest of the parish churches in Jerez de la Frontera, all together, represent a collection of artistic and historical pieces of considerable interest, with some specific examples for their singularity or for their architectonic and decorative distinction, exemplary. Notwithstanding, it would be incongruous to think that these referenced parish baptisteries placed in a larger study of their liturgical functionality, taking as a primary reference the Roman Ritual and the Spanish Synodal Constitutions, would represent a sufficient sample from which to draw larger conclusions regarding the rest of the parishes within the Archdiocese of Seville, or throughout Spain's sphere of influence in the Modern Age.

Keywords: Baptistery, Architecture, Liturgy, Parish, Jerez de la Frontera, Baptismal font, Wrought Iron, Roman Ritual.

El bautismo reviste para el cristiano una importancia superlativa, al ser el primero de los sacramentos, el que borra y purifica todas sus culpas -especialmente las del Pe- cado Original- al tiempo que lo incorpora a la Iglesia. Esta realidad trascendente quedó codificada a través de rúbricas de inmemorial antigüedad que consolidaron lo funda- 
mental de un rito que con el paso del tiempo se fue aquilatando en sus pormenores ceremoniales, pero que sustantivamente se mantenía fiel al mandato de Cristo de bautizar "en el nombre del Padre y del Hijo y del Espíritu Santo"1. . Hasta tal punto el acto del bautismo suponía el más importante de la vida de cualquier cristiano, que era a partir de dicha ceremonia que le venía impuesto su antropónimo, que significativamente, para diferenciarlo de apellidos o apodos, era metonímicamente llamado "nombre de pila" ${ }^{2}$, y su asiento documental, a pesar de ser de índole netamente eclesiástica, sirvió durante siglos como una suerte de registro que también certificaba la propia existencia del bautizado y su filiación ${ }^{3}$.

Esta importancia capital del sacramento requería un lugar adecuado para su desarrollo y engendraba además necesidades materiales específicas que se vieron satisfechas con la aparición de una tipología arquitectónica propia: el baptisterio, que poco

Mateo, 28, 19

2 Otras alusiones metonímicas que ponen de manifiesto cuanto suponía la pila bautismal durante la Edad Moderna serán el uso de pila como sinónimo de feligresía, la perífrasis "sacar de la pila" por apadrinar, o la expresión "cura pilongo", referido al eclesiástico que goza de beneficio en la parroquia donde se bautizó.

${ }^{3}$ Como ha explicado Javier Jiménez “desde finales de la Edad Media, los concilios provinciales y sínodos diocesanos venían señalando la necesidad de dejar constancia de los bautizados con la intención de evitar olvidos, duplicidades sacrílegas en la recepción de sacramentos y fraudes, lo cual se generalizaría para toda la Iglesia a partir del concilio ecuménico de Trento. A la postre, tal decisión terminó siendo providencial, al devenir estos libros, como el resto de los sacramentales, en fuentes casi inagotables de información para los estudios históricos, demográficos y genealógicos, toda vez que en ellos, junto al apunte de la persona bautizada, se incluyen los nombres de sus padres y padrinos, razón por la cual los archivos parroquiales que los custodiaban tuvieron, hasta la creación en España en 1870 del Registro Civil, la consideración de registros públicos". J. E. JIMÉNEZ LÓPEZ DE EGUILETA, "Libro de Bautismos (1487-1507)", en J. E. JIMÉNEZ LÓPEZ DE EGUILETA y P. J. POMAR RODIL (coords.), Limes Fidei. 750 años de Cristianismo en Jerez, Jerez de la Frontera, 2014, p. 228. después del edicto de tolerancia del emperador Constantino comenzó a ser una realidad arquitectónicamente tangible, y cuyo desarrollo artístico posterior correría parejo al de todo el arte cristiano medieval ${ }^{4}$. Para el estudio de las capillas bautismales durante la Edad Moderna resulta indispensable el conocimiento de esa tradición medieval precedente, que supone el fundamento de cuanto a partir de entonces recogieron y expusieron en forma de ley litúrgica positiva las praenotanda y demás rúbricas contenidas en los manuales diocesanos de sacramentos y en el Rituale Romanum, y que con frecuencia encontraron también reflejo en las distintas constituciones emanadas de los sínodos y concilios locales que se ocuparon del efectivo ajuste entre el modelo teórico general y las costumbres particulares, que es cuanto el presente trabajo, que toma como muestra de estudio los baptisterios parroquiales de Jerez de la Frontera, trata de reflejar ${ }^{5}$.

${ }^{4}$ Una introducción al origen de los baptisterios en el contexto de la arquitectura sacra posterior a la paz de la Iglesia en P. TESTINI, Archeologia cristiana. Nozioni generali dalle origini alla fine del sc. VI, Bari, 1980, pp. 619638.

5 En la ciudad de Jerez existían nueve pilas bautismales. La colegiata de San Salvador fue siempre templo parroquial de su collación, contando con su correspondiente baptisterio como el resto de parroquias de la fundación alfonsina (San Mateo, San Marcos, San Lucas, San Juan y San Dionisio) y las de los nuevos arrabales extramuros (San Miguel y Santiago). También dispondría de pila, pese a no ser parroquia, la capilla de San Juan de Letrán, situada en los llamados Llanos de San Sebastián. El motivo de esta singularidad canónica la explica el visitador don Gonzalo de Mier en 1673, quien señala que, tras fracasar el intento de erección como colegiata exenta, el arzobispo decidió dotarla de cura y sacristán para "que cuide del sagrario y de renovar y confesar y baptizar a todos los párvulos quienes sean baptizados en dicha iglesia, así por la mucha gente que hay en esta ciudad, como por que los que fuesen pobres pudiesen ir a cualquiera hora. $Y$ así se continúa y frecuenta esto mucho, porque todas las personas pobres acuden a dicha iglesia". Archivo General del Arzobispado de Sevilla (en adelante AGAS), Sección II, Visitas, Legajo 1443, s/fol. 


\section{UBICACIÓN Y ORIENTACIÓN}

El ineludible paso por la pila bautismal quedó regulado en la Archidiócesis de Sevilla por las Constituciones sinodales, que ordenaban que tuviese lugar en el plazo máximo de ocho días tras el nacimiento de la criatu$\mathrm{ra}^{6}$. La primera parte de la ceremonia en que se confería el sacramento solía tener lugar en el atrio del templo o al ingreso del mismo. Allí el cura, tras exhortar catequéticamente a los padrinos de las obligaciones que contraían, hacía el signo de la cruz al párvulo, bendecía la sal y se la imponía, y pronunciaba sobre él los exorcismos previstos junto con otros signos y oraciones. A continuación se pasaba en una breve procesión hasta el baptisterio, que por razones tan simbólicas como prácticas se situaba en una capilla ubicada junto a la puerta principal del templo o cercana a ella. En este espacio, que normalmente quedaba reservado exclusivamente para esta celebración, tenían lugar otra serie de ritos entre los cuales se encontraba el bautismo propiamente dicho, administrado casi siempre por infusión con la triple fórmula trinitaria prevista en el Ritual ${ }^{7}$.

La vieja catedral de Sevilla, fruto de la adaptación de su aljama islámica al culto cristiano, tenía su pila bautismal prácticamente al ingreso del llamado claustro de los Caballeros, esto es, en el mismo sitio que luego ocupó en la catedral gótica ${ }^{8}$. En las

\footnotetext{
${ }^{6}$ Constituciones del Arzobispado de Sevilla hechas y ordenadas por el Ilustrísimo y Reverendísimo Sr. D. Fernando Niño de Guevara, Cardenal y Arzobispo de la Santa Iglesia de Sevilla, en el Sínodo que celebró en su Catedral año de 1604; y mandadas imprimir por el Deán y Cabildo, Canónigos in Sacris, Sede vacante, en Sevilla, año de 1609, Sevilla, 1864, T. II, p. 57.

7 El desarrollo ceremonial puede seguirse en el propio Ritual, teniendo también en cuenta los complementos del Manual Toledano incluido como apéndice de aquel en las ediciones hispanas. Rituale Romanum Pauli V. P. M. iussu editum [1614], Roma, 1615, pp. 11-59.

8 T. LAGUNA PAÚL, "La Aljama cristianizada. Memoria de la catedral de Santa María de Sevilla", en Metropolis Totius Hispaniae, Sevilla, 1993, p. 57; A. JIMÉNEZ MARTÍN e I. PÉREZ PEÑARANDA,
}

parroquias jerezanas sólo encontramos dicha ubicación en la de San Marcos (Fig. 1), que tuvo situado su baptisterio en la última capilla del lado del evangelio, hasta que, al ampliarse la iglesia por los pies a finales del XV o principios del XVI, pasase a ser la segunda capilla de este lado'. Curiosamente esta ubicación accidental del baptisterio de San Marcos coincide con la que tendría el de la catedral de Sevilla a partir de 1656, cuando la pila fue trasladada a la capilla contigua para dejar expedito el paso a la iglesia del Sagrario ${ }^{10}$. De planta poligonal y bóveda gallonada con unos sorprendentes merlones escalonados en su interior, ha sido imprecisamente datada entre avanzado el siglo XIV y la primera mitad del siglo siguiente, y por tanto pervivencia del antiguo San Marcos levantado sobre la mezquita preexistente ${ }^{11}$. Es sin duda una pieza rara por su singularidad arquitectónica, y como tal ha sido tratada por la historiografía ${ }^{12}$.

Cartografía de la Montaña hueca. Notas sobre los planos históricos de la catedral de Sevilla, Sevilla, 1997, p. 115.

9 Sobre la reforma bajomedieval de San Marcos vid. M. ROMERO BEJARANO, "Del mudéjar al gótico. Arquitectura religiosa a finales del XV en Jerez", en 750 aniversario de la incorporación de Jerez a la Corona de Castilla: 1264-2014, Jerez de la Frontera, 2014, pp. 452453.

${ }^{10}$ A. JIMÉNEZ MARTÍN e I. PÉREZ PEÑARANDA, Op. cit., p. 115.

11 F. LÓPEZ VARGAS-MACHUCA, "Entre la tradición castellana y la herencia andalusí. La arquitectura religiosa en Jerez de la Frontera desde la conquista cristiana hasta la irrupción del tardogótico (1264-1464)", en J. E. JIMÉNEZ LÓPEZ DE EGUILETA y P. J. POMAR RODIL (coords.), Op.cit., pp. 83-84.

12 No podemos descartar que el derribo del hastial occidental para la ampliación del templo por los pies, hubiese supuesto la desaparición de un baptisterio abierto a este y el traslado de la pila a la pieza arquitectónica que tratamos. Sin embargo, su extraordinaria singularidad arquitectónica, inusual en el tipo funerario que pudiera ser su alternativa funcional, en la que el único paralelo aproximado sería la capilla de los Hinestrosa de la parroquia sevillana de Santa Marina, nos lleva a creer más probable que en efecto la capilla hubiese sido el baptisterio de San Marcos desde su origen. 


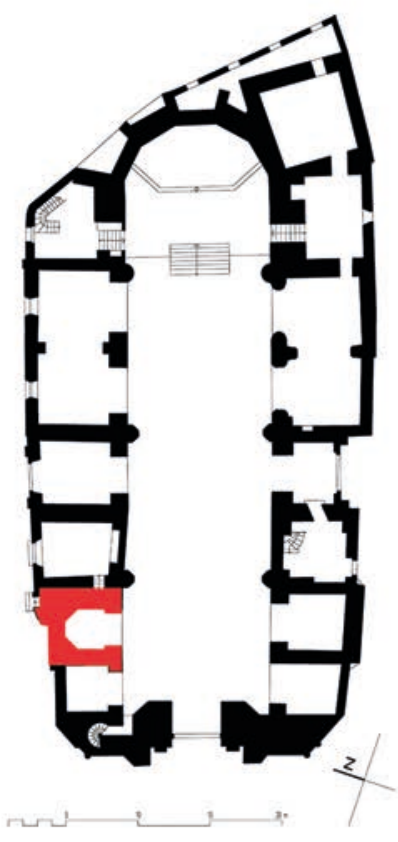

San Marcos
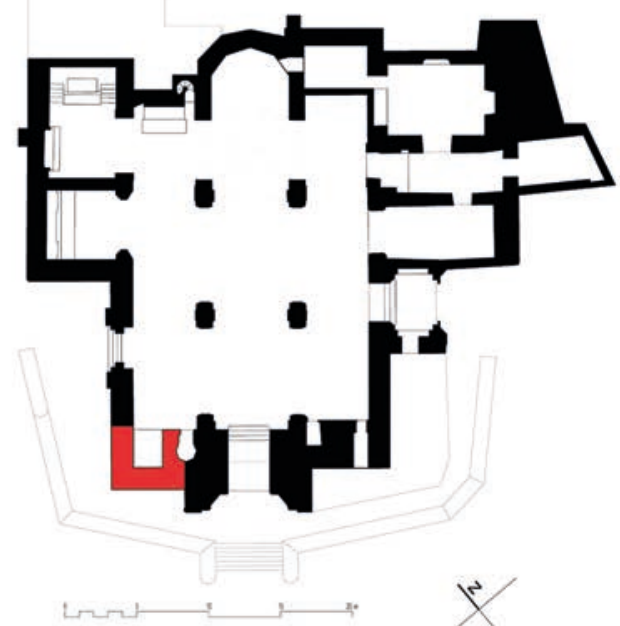

San Lucas

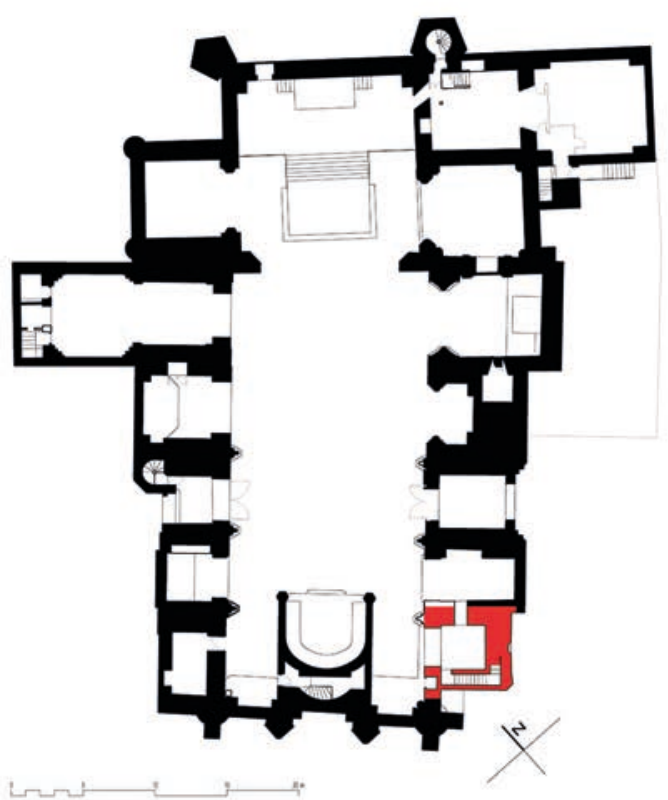

San Mateo
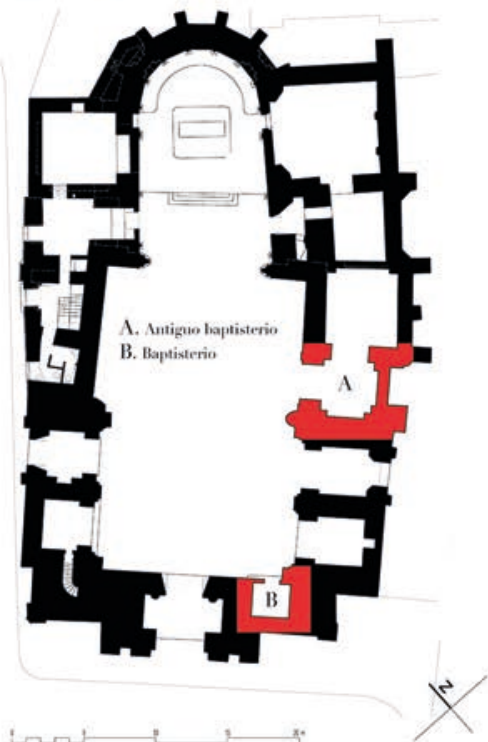

San Juan de los Caballeros

- Fig. 1. Ubicación de los baptisterios de las parroquias de San Marcos, San Mateo, San Lucas y San Juan de los Caballeros. Planos del autor

Sólo el baptisterio de San Lucas comparte con el de San Marcos la posición en el lado del evangelio, si bien en este caso se encuentra en una pequeñísima capilla abierta al hastial de los pies del templo (Fig. 1); la ausencia de otros espacios lleva a pensar que esta ubicación hubiese sido la destinada a este fin desde el origen del templo cristiano medieval, acaso con el precedente de una pila cercada de cancelas como pudo suceder en otras iglesias antes de contar con un espacio arquitectónico independiente. En cualquier caso, el lenguaje arquitectónico que exhibe en la actualidad es netamente barroco, 
fruto de la reforma general del edificio llevada a cabo durante el primer tercio del siglo XVIII y que en este concreto espacio ocupó al maestro Adrián Baptista a partir de 1728, que lo dotó de su característica bóveda de yesería, de abigarrada hojarasca ${ }^{13}$.

El resto de parroquias, por el contrario, ubicaron la pila bautismal en capillas situadas en el lado de la epístola, y para ello quizá fue decisivo el que en ese lugar la tuviese la colegiata antigua ${ }^{14}$. La colegiata llevaba aparejada la condición parroquial desde sus orígenes, teniendo su cabildo encomendada corporativamente la cura de almas de la collación ${ }^{15}$. Esto la obligaba a contar con una pila para la administración del bautismo a sus parroquianos, que inicialmente podría haber quedado ubicada en un eventual acotamiento hecho a los pies de la mezquita ya cristianizada y orientada, probablemente junto al antiguo muro de la alquibla. Sería esta la misma ubicación que conservaría en el templo medieval cristiano en que paulatinamente quedó convertida aquella aljama, según mostraría la planta que de aquel desaparecido edificio alcanzó a ver el canónigo Mesa Ginete, quien confirma la ubicación de la pila a los pies del templo, en una capilla de la nave de la epístola ${ }^{16}$. Poco sabemos de su estructura y forma constructiva, mas cabe pensar en una solución arquitectónica

${ }^{13}$ F. AROCA VICENTI, Arquitectura y Urbanismo en el Jerez del siglo XVIII, Jerez de la Frontera, 2002, p. 202; J. M. MORENO ARANA, "La transformación barroca de la iglesia de San Lucas de Jerez en el siglo XVIII", en F. PÉREZ MULET (coord.), Nuevas aportaciones a la Historia del Arte en Jerez de la Frontera y su entorno, Cádiz, 2016, p. 116.

${ }^{14}$ J. E. JIMÉNEZ LÓPEZ DE EGUILETA y P. J. POMAR RODIL, "La colegiata medieval de San Salvador de Jerez de la Frontera", en 750 aniversario..., pp. 477-478.

${ }^{15} \mathrm{~J}$. L. REPETTO BETES, Historia del Cabildo Colegial de Jerez de la Frontera. 1264-1984, Jerez de la Frontera, 1986, pp. 451-454.

${ }^{16}$ F. de MESA GINETE, Historia Sagrada y Política de la Muy Noble y Muy Leal Ciudad de Tarteso, Turdeto, Asta Regia, Asido Cesariana, Asidonia, Gera, Jerez Sidonia, hoy Jerez de la Frontera [1754], Jerez de la Frontera, 1888, T. II, p. 107. sencilla, de traza cuadrangular y cubierta abovedada, que acaso pudo ser renovada en 1488 cuando fue vendida por la fábrica a los Sánchez de Cádiz para su propio enterramiento $^{17}$. A pesar de esta enajenación, la capilla continuó lógicamente desempeñando su función como baptisterio, uso que quedó garantizado en el contrato de compraventa ${ }^{18}$.

Este tipo de acuerdos con particulares para un uso compartido del baptisterio, algo que siglos más tarde parecería impensable, no fueron raros a finales de la Edad Media; no hay más que recordar el caso de la catedral de Sevilla, que tenía junto a su pila el altar de la Santa Angustia, que había sido dotado en $1401^{19}$. De hecho, en Jerez hubo otro caso en la parroquia de San Dionisio (Fig. 2), donde la pila se encuentra en la capilla de Elvira Martínez de Trujillo Maldonado, apodada "la Astera" en la documentación histórica por ser viuda de Alonso Sánchez, acaso astero de profesión ${ }^{20}$. Dicha capilla, que se levantó en torno a 1430, consta de tres partes bien diferenciadas: la oriental era el presbiterio de la misma, que contaba con el altar y los enterramientos; la parte occidental era usada por la parroquia como baptisterio y la central serviría para la asistencia de los fieles tanto a las misas ofrecidas en memoria de los patronos, como a los bautizos de los niños de

\footnotetext{
${ }^{17}$ Ibídem.

18 "e han de tener la dicha capilla con tal condiçión que esté en ella siempre la dicha pila de bautizar e que la dicha iglesia se syrva della en este caso e que a costa de dicho Ruy Sánchez de Cádiz se ponga a la dicha capilla sus rejas de fierro e se adobe e repare cada e quando lo oviere menester para siempre jamás e con esta condición la dicha iglesia les dé para la dicha capilla para sepultar los que por línea recta vinieren de los dichos Juan Sánchez e Ruy Sánchez de Cádiz". Archivo Histórico Diocesano de Jerez de la Frontera (en adelante AHDJF), Fondo Colegial, Sección II, Caja 21, Documento 44/2, fols. 2v.-25v. Agradecemos a don Javier Jiménez López de Eguileta que nos haya facilitado el presente documento inédito.

${ }^{19}$ A. JIMÉNEZ MARTÍN e I. PÉREZ PEÑARANDA, Op. cit., p. 115.

${ }^{20} \mathrm{H}$. SANCHO DE SOPRANIS, “El arte mudéjar en Jerez", en Actas del I congreso de estudios árabes e islámicos, Madrid, 1964, pp. 417-421.
} 
la feligresía ${ }^{21}$. En cierto modo, casi podemos afirmar que el baptisterio parroquial estaba abierto a la capilla de la Astera más que formar parte de la misma.

En la misma ubicación que en la colegiata, ocupando la última capilla del lado de la epístola, se encontraría también el pequeño baptisterio de San Mateo (Fig. 1), obra del segundo tercio del $\mathrm{XV}$, que destaca por la bóveda estrellada con que se cubre, con decoración de dientes de sierra en sus nervios y puntas de diamantes en la línea de impostas ${ }^{22}$. Igual ubicación mantiene el primitivo baptisterio de San Juan de los Caballeros (Fig. 1), que comparte con éste de San Mateo lenguaje arquitectónico, acaso de cronología algo anterior, si bien no necesariamente ${ }^{23}$. Su posterior conservación como capilla funeraria de don Felipe Zarzana, con la portada trazada por el milanés Vermondo Resta en 1596 nos ha permitido conocer el límite occidental que tuvo el templo hasta el siglo XVI, dado que, como se ha señalado, los baptisterios están siempre ubicados en la cercanía de la puerta de los pies de la iglesia ${ }^{24}$.

${ }^{21}$ Un largo pleito entre los herederos de la Astera en el siglo XVIII y la fábrica de San Dionisio señala que la pila estaba situada en aquel lugar "con el permiso de los patronos, por no aver en la dicha iglesia sitio más oportuno y porque no estando dicha pila en el medio de la capilla no embaraza el uso libre y concurrencia de los fieles a las misas y aniversarios que por dicha fundadora se dicen en ella todos los días". F. LÓPEZ VARGASMACHUCA, El edificio medieval de San Dionisio de Jerez de la Frontera, Jerez de la Frontera, 2014, p. 31.

22 F. LÓPEZ VARGAS-MACHUCA, "Entre la tradición castellana...", pp. 81-82.

${ }^{23}$ Ambas capillas se cubren con bóveda de terceletes. La de San Mateo, eso sí, es mucho más mudéjar al absorber la forma qubba, incluyendo trompas de arista viva en las esquinas. A pesar de todo, la intensísima restauración sufrida por la de San Juan durante la última década del siglo XIX complica sobremanera su precisa datación. M. Á. ÁlVAREZ LUNA, J. M. GUERRERO VEGA y M. ROMERO BEJARANO, La intervención en el patrimonio. El caso de las iglesias jerezanas (1850-2000), Jerez de la Frontera, 2003, p. 108.

${ }^{24}$ F. de MESA GINETE, Op. cit., T. II, p. 141; H. SANCHO DE SOPRANIS, "La arquitectura jerezana en el siglo XVI", Archivo Hispalense, no 123, 1964, p. 27.
Este mismo criterio ha servido para certificar la importante dimensión que debió de tener el Santiago medieval anterior a la fábrica tardogótica, dado que el desaparecido baptisterio (Figs. 2 y 3), ubicado en el hastial Oeste del templo, junto a la puerta de los pies, marcaría el límite occidental de aquel templo, mientras que el oriental, que desconocemos, habría de alcanzar al menos hasta la capilla de la Paz, ambas piezas de similar cronología y tipo constructivo al de los baptisterios de San Mateo y San Juan anteriormente tratados, esto es, de en torno a $1430^{25}$. Esta ubicación en el hastial occidental del templo, a los pies de la nave de la epístola, sería luego seguida por las parroquias de San Miguel y San Juan. La primera, que mantenía con Santiago un constante juego de competencia y piadosa emulación, levantó hacia 1525 un baptisterio cuya portada y bóveda casi plana son verdaderos alardes de la estereotomía tardogótica (Figs. 2 y 4$)^{26}$. El nuevo baptisterio de San Juan de los Caballeros, levantado mediado el siglo XVI, probablemente bajo la dirección de Hernán Ruiz II, reproduce idéntica ubicación (Fig. 1), si bien con un lenguaje arquitectónico ya plenamente clásico ${ }^{27}$.

25 El baptisterio de Santiago desapareció en las obras de restauración de los años sesenta del siglo XX, que estuvieron a cargo del arquitecto Francisco Pons-Sorolla y Arnau, pero tanto Romero de Torres como Esteve Guerrero, que alcanzaron a verlo en pie, coinciden en señalar que compartía idéntica decoración arquitectónica con la capilla de la Paz, considerando ambas del mismo periodo arquitectónico anterior al de la gran fábrica tardogótica. No obstante lo dicho, ya Hipólito Sancho advertía de que "una restauración bien visible a primera vista, obliga a grandes precauciones al estudiarla". E. ROMERO DE TORRES, Catálogo monumental de la Provincia de Cádiz (1908-1909), Madrid, 1934, T. I, p. 420; M. ESTEVE GUERRERO, Jerez de la Frontera (Guía oficial de arte), Jerez de la Frontera, 1933, p. 116; H. SANCHO DE SOPRANIS, Introducción al estudio de la arquitectura en Xerez, Jerez de la Frontera, 1934, p. 19; M. Á. ÁlVAREZ LUNA, J. M. GUERRERO VEGA y M. ROMERO BEJARANO, Op. cit., p. 87.

${ }^{26} \mathrm{M}$. ROMERO BEJARANO, Maestros de obras de ascendencia portuguesa en el tardogótico de la baja Andalucía, Tesis doctoral inédita defendida en la Universidad de Sevilla, 2014, pp. 349-354.

27 A. J. MORALES MARTÍNEZ, Hernán Ruiz 


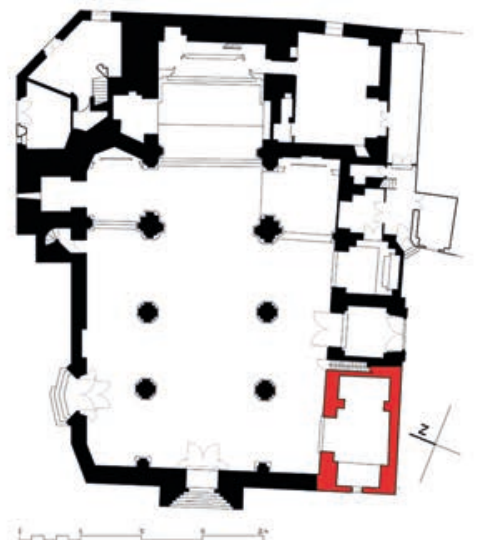

San Dionisio

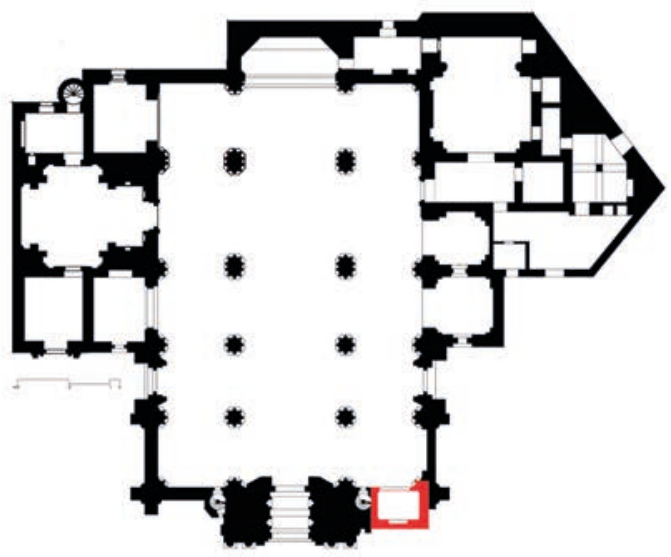

San Miguel
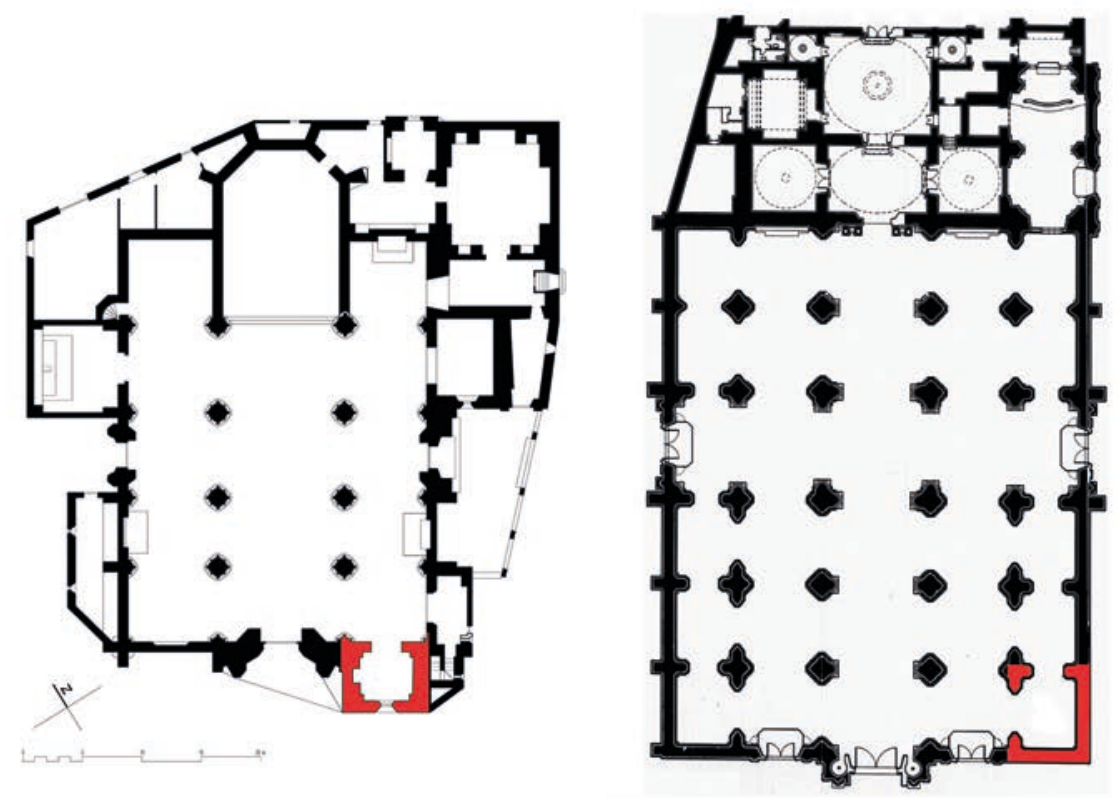

Colegiata de San Salvador

- Fig. 2. Ubicación de los baptisterios de las parroquias de San Dionisio, San Miguel, Santiago y la Colegiata de San Salvador. Planos del autor.

Siempre en relación con la situación del baptisterio hay que considerar su orientación, de tanta importancia en el culto cristia-

"el joven", Madrid, 1996, p. 70; M. Á. MARISCAL RODRÍGUEZ, y P. J. POMAR RODIL, Jerez. Guía artística y monumental, Madrid, 2004, p. 63. no. En efecto, la ubicación de la capilla bautismal en el testero de los pies del templo, en posición completamente opuesta al altar mayor, permite a su vez el mantenimiento de la orientación en la celebración del rito pues, al ubicarse el sacerdote entre la pared occidental de la capilla y la pila, podía mantener 


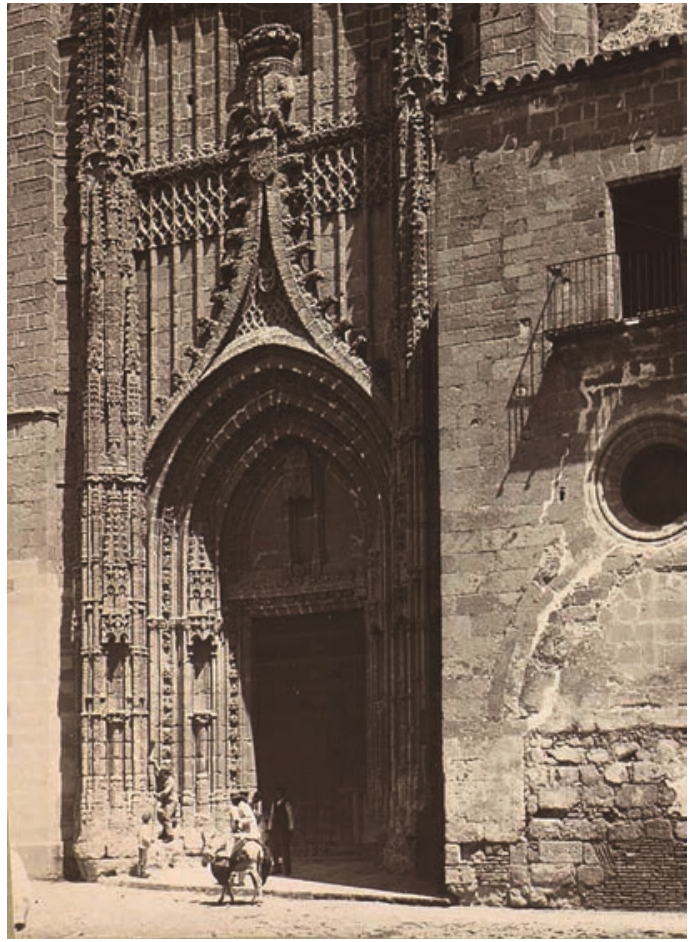

- Fig. 3. Vista exterior del desaparecido baptisterio de la Parroquia de Santiago. 1908. Foto de Enrique Romero de Torres.

la dirección al oriente litúrgico que marcaba el altar mayor y que en este caso quedaría evocado por el altar de la nave de la epístola -o del evangelio en el caso de San Lucas- al cual se dirigiría el sacerdote en la ceremonia ante la ausencia de altar en los baptisterios jerezanos.

Todo este razonamiento teórico podría parecernos un tanto alambicado de no contar con ejemplos locales que en efecto parecen probarlo. En primer lugar tenemos que tener en cuenta algunas de las ubicaciones que escaparían a la regla, como serían las de los baptisterios de la vieja colegiata de San Salvador y de la parroquia de San Dionisio. En ambos casos la capilla no se encontraba en el testero de los pies sino abierta al muro de la epístola, pero ambas contarían con altares propios levantados por las familias Sánchez de Cádiz y Martínez de Trujillo respectivamente que, como fue habitual hasta finales de la Edad Media, compartían orientación con el mayor del templo ${ }^{28}$. De este modo, la pila ubicada frente al altar permitía mantener el eje Oeste-Este durante la ceremonia, dado que el sacerdote se ubicaría dando la espalda al testero occidental de la capilla. La leyenda contenida en el plano del siglo XVIII de la capilla bautismal de San Dionisio (Fig. 5) explica claramente como esta había sido una suerte de iglesia en miniatura, con su arco toral y presbiterio, frente al cual se encontraba la pila, dispuesta de tal manera que el sacerdote al conferir el bautismo enfrentase el altar ${ }^{29}$. La iconografía que albergaba su retablo, una imagen de Nuestra Señora de la Candelaria rescatada recientemente, estaría además en estrecha relación con el sacramento del bautismo, dado que el día de la Candelaria no es sino el de la Presentación del Niño Jesús al Templo, prefigurativo antecedente judaico de la práctica cristiana del bautismo de párvulos ${ }^{30}$. Además, la propia

${ }^{28}$ Véase la ubicación de los altares de las capillas laterales de la catedral de Sevilla, por ejemplo, orientados todos como el mayor del templo.

29 F. LÓPEZ VARGAS-MACHUCA, El edificio medieval..., pp. 30-35.

30 La imagen, que se encontraba guardada en dependencias del templo, fue expuesta por vez primera durante la exposición Limes Fidei y con tal motivo estudiada por Salvador Hernández que la dató hacia los años finales del siglo XV. En el catálogo de aquella exposición, Fernando López aventuraba la posibilidad de que la imagen fuese la titular del retablo que nos ocupa. La posición de la mano izquierda de la imagen en posición de sostener un elemento cilíndrico de manera perfectamente vertical parece descartar la idea de que fuese un cetro, que es más frecuentemente portado ligeramente al bies, y sin embargo evoqua la del cirio, que necesariamente ha de sostenerse así para evitar la caída de la cera. El visitador don Juan Bejarano Muñoz describe en 1705 el baptisterio de San Dionisio y advierte de que en él existía un "altar y retablo dorado y en él dicha imagen pequeña de bulto de Nuestra Señora de la Candelaria". Esta descripción nos permite confirmar la identificación iconográfica que ya presumíamos y por tanto casi garantizar su procedencia. S. HERNÁNDEZ GONZÁLEZ, “Virgen con el Niño”, en J. E. JIMÉNEZ LÓPEZ DE EGUILETA y P. J. POMAR RODIL (coords.), Limes Fidei..., pp. 288-289; F. LÓPEZ VARGAS-MACHUCA, “Entre la tradición castellana...", p. 97, nota. 41; AGAS, Sección II, Serie visitas, Legajo 1348, fols. 24r.-28r.. 


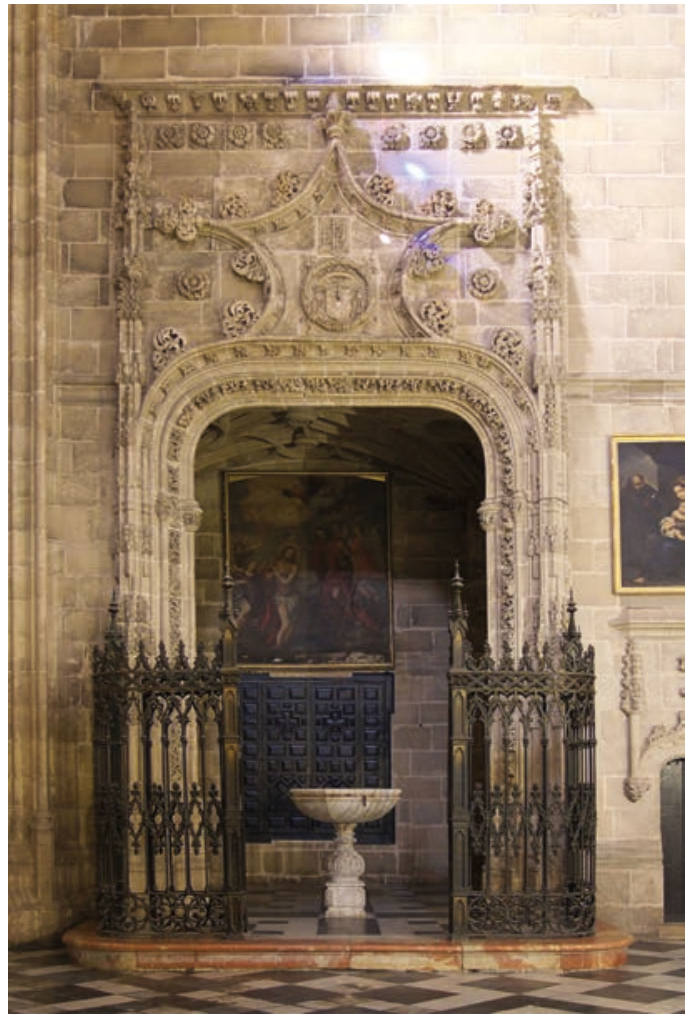

- Fig. 4. Baptisterio de la Parroquia de San Miguel. Foto del autor.

iconografía de la Virgen, con un cirio encendido en la mano hace referencia explícita a la figura del padrino o madrina que adopta idéntica actitud durante la ceremonia cristiana del bautismo ${ }^{31}$.

Qué duda cabe de que con la proliferación de altares laterales dispuestos en cualquier dirección, al darse durante la Edad Moderna la disociación absoluta de la orien-

\footnotetext{
${ }^{31}$ Todo lo dicho sin menoscabo de que la otra función de esta capilla, la funeraria, influyese igualmente en la elección de la iconografía que nos ocupa. De hecho, a la advocación de la Candelaria se le ha supuesto una cierta finalidad simbólica en ámbitos funerarios, al hacer referencia a la oración del Nuc dimittis pronunciada por el anciano Simeón durante la presentación del Niño Jesús al Templo: “Ahora, Señor, puedes, según tu palabra, dejar que tu siervo se vaya en paz; porque han visto mis ojos tu salvación, la que has preparado a la vista de todos los pueblos" (Lucas 2, 29-32). Vid. S. HIDALGO SÁNCHEZ, "Una iconografía funeraria en la capilla Barbazana: La Virgen de la Candelaria", Cuadernos de la Cátedra de Patrimonio y Arte Navarro, $\mathrm{n}^{\circ}$ 1, 2006, p. 68.
}

tación cardinal respecto de la litúrgica ${ }^{32}$, todo lo anteriormente señalado se vio oscurecido hasta el punto de que el propio altar de la capilla bautismal de San Dionisio cambió su ubicación y se colocó en 1737 frontero al ingreso a la capilla ${ }^{33}$. Sin embargo, también contamos con un ejemplo de apenas veinte años antes en la parroquia de San Lucas, donde el visitador don Pedro Fernández de Zurita apelaba a aquellos mismos principios de orientación litúrgica al solicitar "que a la tapa de la pila baptismal se abra por el lado del testero principal de la capilla donde esta dicha pila y en dicho citio se ponga el ministro para hacer los baptismos y evitar la yrreverencia de estar de espaldas a el altar que esta frente de dicha capilla", esto es, al altar de Santa Ana que presidía la nave del evangelio en paralelo con el mayor ${ }^{34}$.

\section{LA PILA BAUTISMAL}

Inicialmente las pilas de las parroquias jerezanas habrían sido realizadas en terracota vidriada, probablemente por talleres trianeros, como fueron la mayor parte de las del arzobispado hispalense (Fig. 6) ${ }^{35}$. Sin embargo, a partir del siglo XVI fueron siendo sustituidas por otras de mármol en consideración de la mayor dignidad de la piedra frente a la tierra para contener el agua bautismal;

${ }^{32}$ Sobre el cambio de paradigma entre orientación cardinal y litúrgica vid. S. de BLAAUW, "Innovazioni nello spazio di culto fra basso Medioevo e cinquecento: La perdita dell'orientamento liturgico e la liberazione della navata", en J. STABENOW (coord.), Lo spazio e il culto. Relazioni tra edificio eclesiales e uso liturgico dal XV al XVI secolo, Venezia, 2006, pp. 25-51.

${ }^{33}$ Además, en 1775 fue sustituido por uno nuevo de estilo rococó, obra del retablista Andrés Benítez y dotado de una nueva y caprichosa iconografía. F. LÓPEZ VARGAS-MACHUCA, El edificio medieval..., p. 31; H. SANCHO de SOPRANIS, "El arte mudéjar...", p. 419; J. M. MORENO ARANA, El retablo en Jerez de la Frontera durante el siglo XVIII, Sevilla, 2014, pp. 450-451.

${ }^{34}$ AGAS, Sección II, Serie visitas, Legajo 1359, fol. $227 r$.

35 J. GESTOSO y PÉREZ, Historia de los barros vidriados sevillanos desde sus orígenes hasta nuestros días, Sevilla, 1903, p. 143. 


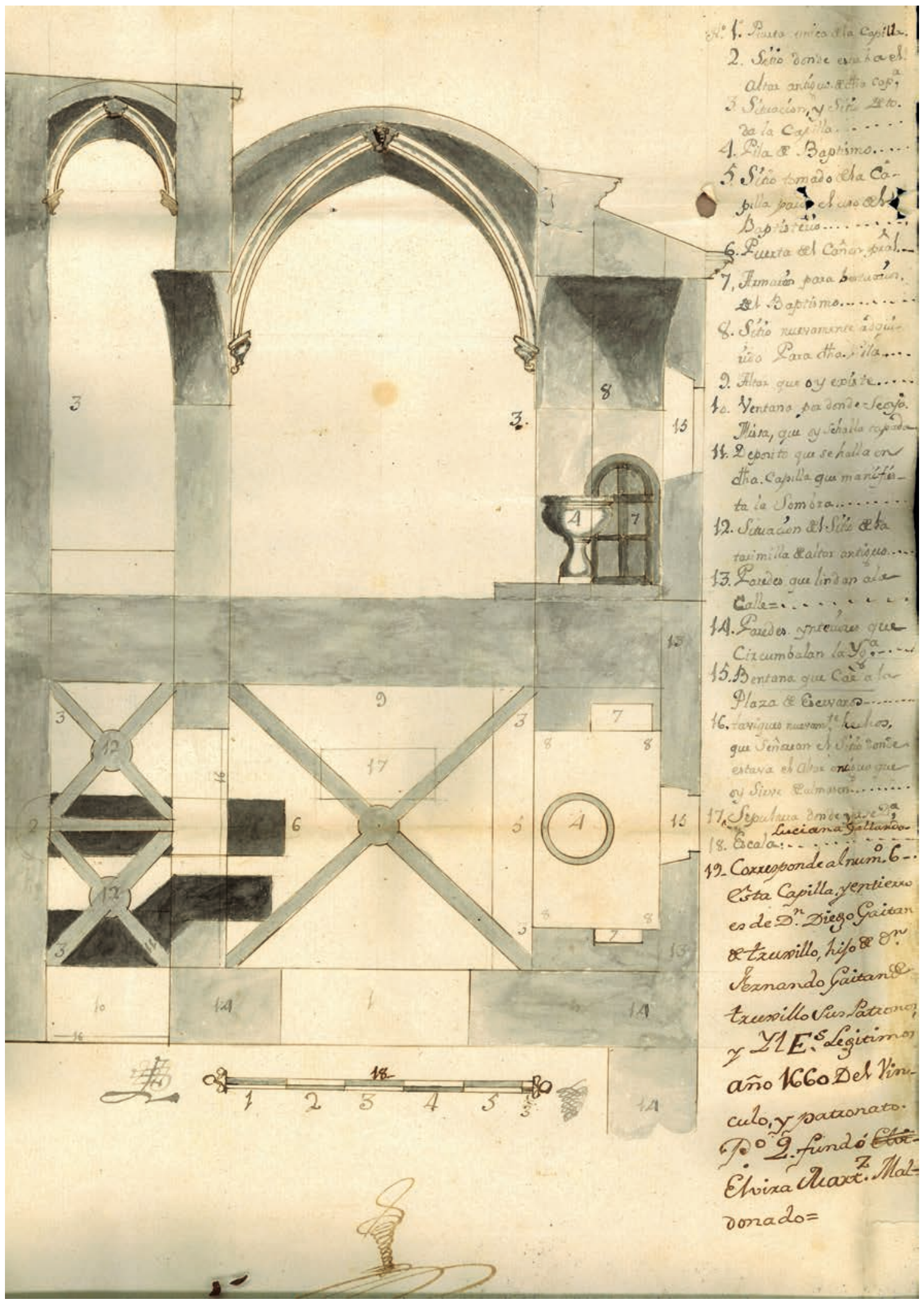

- Fig. 5. Planta y alzado de la Capilla de la Astera, baptisterio de la Parroquia de San Dionisio. S. XVIII. Archivo Histórico Diocesano de Jerez de la Frontera. 
como se constata en la colegial del Salvador cuando el canónigo Fernando Flores donó en 1548 la pila plateresca de mármol que todavía se conserva en el nuevo templo barroco (Fig. 7) ${ }^{36}$. Acelerador de este proceso debió de ser la aparición en 1614 del nuevo Rituale Romanum, que establecía la necesidad de que la pila bautismal estuviese realizada en materia digna y sólida ${ }^{37}$. No lo parecería la terracota y así, en el entorno de la archidiócesis sevillana, encontramos una referencia explícita al asunto en las Constituciones del sínodo diocesano de Málaga de 1671, de Fray Alonso de Santo Tomás, donde se ordena "que la pila sea de piedra, y no de barro, y donde ha quedado alguna, se consuma dentro de dos meses, y se haga de piedra" ${ }^{\prime 38}$. Parecido celo litúrgico movería al arzobispo don Jaime de Palafox y Cardona cuando visitó las parroquias de Jerez en 1691, pues al revisar la pila de San Lucas, que era "de barro vidriado de color verde", estableció "que se ponga una pila baptismal de piedras jaspe o alabastro en el lugar de la que hay de barro y ésta se rompa y se entierre" ${ }^{\prime \prime 3}$. Se debió de ejecutar la petición, pues en la resulta de la visita de don Juan Bejarano Muñoz en 1705

\footnotetext{
${ }^{36}$ La inscripción de la pila, que lleva el escudo del donante, ha servido recientemente para su precisa datación: HAVRIETIS AQVAS INGAVDIU DEFONTIBVS SALVATORIS FER. FLORES. PROTONOTARVS APPOSTOLICVS ET CANONICVS D.D.D. AN MDXLVIII. J. E. JIMÉNEZ LÓPEZ DE EGUILETA, y P. J. POMAR RODIL, “La colegiata medieval...", p. 478, nota 115 .

${ }^{37}$ Rituale Romanum..., p. 8.

${ }^{38}$ F. A. de SANTO TOMÁS, Constituciones synodales del Obispado de Málaga, Sevilla, 1674, p. 274.

39 Curiosamente encontramos un mandato de Palafox idéntico para la pila de San Mateo, que había de destruirse, enterrarse y sustituirse por una de jaspe o alabastro en el plazo de cuatro meses; sin embargo, en 1673 el visitador don Gonzalo de Mier y Barreda nos la describe como "de piedra". Resulta inverosímil pensar que una eventual rotura de esta pila pétrea fuese subsanada a estas alturas con su sustitución por una de barro, por lo que muy probablemente o Mier hace una apreciación incorrecta, o el escribano a disposición de Palafox duplicase el mandato de San Lucas por error. AGAS, Sección II, Serie visitas, Legajos 1443, s/fol.; 1339, fols. $45 \mathrm{v}$. y $48 \mathrm{v}$.
}

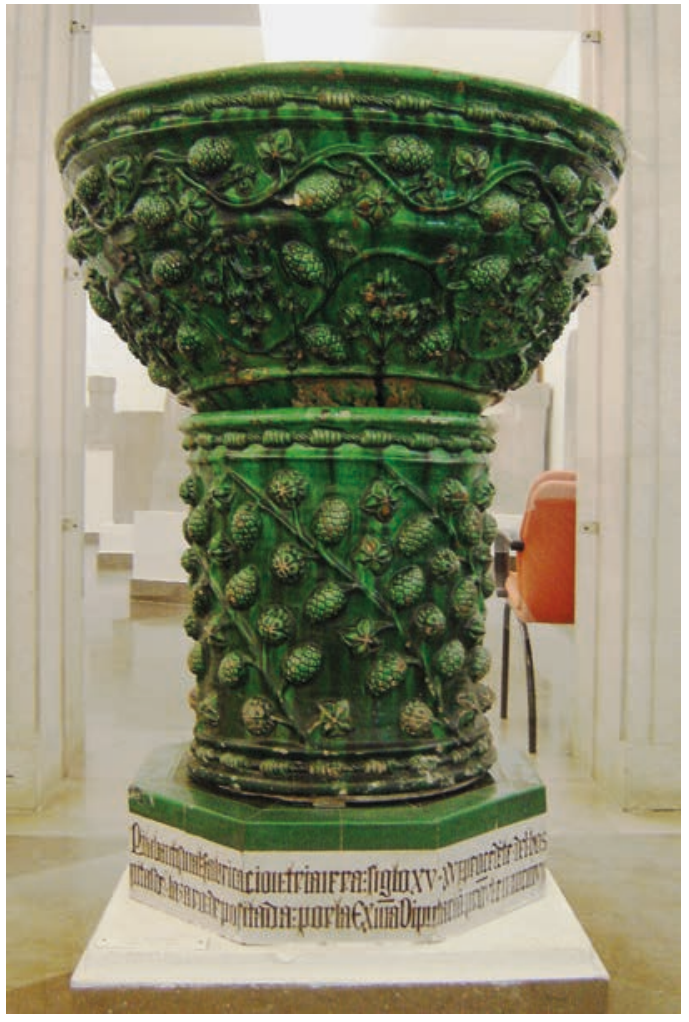

- Fig. 6. Pila bautismal del Hospital de San Lázaro de Sevilla. Museo Arqueológico de Sevilla. Foto del autor.

la pila aparece ya descrita como una pieza de mármol blanco ${ }^{40}$. Por lo demás, desde el siglo XVII sabemos que el resto de pilas de parroquias jerezanas estaban realizadas en distintos tipos de piedra (Fig. 8) y por tanto cumplían con los requisitos del Ritual tal como habían sido interpretados ${ }^{41}$.

La higiene de la pila suponía un cuestión fundamental sobre la que había que tener el mayor cuidado, dado que su agua, que se consagraba durante la vigilia de Pen-

${ }^{40}$ Ibídem, Legajo 1348, s./fol.

${ }^{41}$ Las distintas visitas de los siglos XVII y XVIII informan de algunos detalles materiales de estas piezas, como la pila de San Dionisio, "de jaspe negro muy grande y bien labrada", que aún se conserva; la de San Marcos y Santiago, que eran de piedra martelilla, conservándose la primera; la de San Miguel, de mármol rojo y blanco, pero que fue sustituida por una de nueva factura tras el terremoto de 1755 que la destruyó; siendo el resto de mármol blanco. Ibídem, Legajos 1443, s/fol.; 1348, fols. 24r-28r; F. AROCA VICENTI, Arquitectura y urbanismo...., p. 224. 


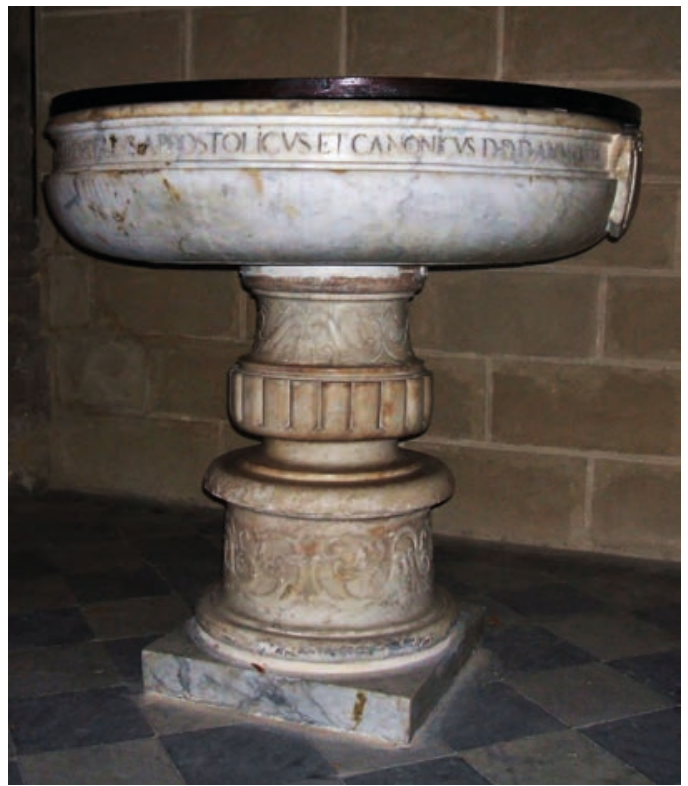

- Fig. 7. Pila bautismal. 1548. Colegiata de San Salvador - Catedral de Jerez. Foto del autor.

tecostés, debía durar en buen estado casi un año, hasta el Sábado de Gloria siguiente en que se volvía a renovar y consagrar ${ }^{42}$. A tal fin, una de las medidas previstas por el Ritual era que la pila contase con una tapadera completa que impidiese la entrada de polvo en la misma ${ }^{43}$. Sin duda, esta tapadera además contribuiría a evitar la evaporación y, al impedir la entrada de luz solar, el crecimiento de verdín y nacimiento de gusarapos que terminarían por corromper el agua, razón por la que también en las anteriormente mencionadas constituciones malagueñas de Fray Alonso de Santo Tomás se ordene encarecidamente que la pila de cada parroquia "esté con cubierta y cerrada con llave" ${ }^{44}$. Al respecto, hay que señalar que en toda la documentación resultante de las visitas pastorales estudiadas no hemos hallado un solo caso de agua corrompida, si bien hemos de

${ }^{42}$ Existían no obstante recursos previstos por los liturgistas por si el agua de la pila se consumiese, disminuyese, se congelase o se corrompiese, exigiendo este último caso desechar todo el agua, la limpieza de la pila, su oreo y una nueva consagración con la fórmula recogida en el Ritual para hacerlo fuera de los dos sábados previstos. Rituale Romanum..., pp. 47-51.

\footnotetext{
${ }^{43}$ Ibídem, p. 8.

${ }^{44}$ F. A. de SANTO TOMÁS, Op. cit., p. 274.
}

suponer que eventualidades tan lamentables pudiesen ser corregidas ante la inminente llegada del visitador ${ }^{45}$.

Las cubiertas de madera cerradas con llave son comunes a todas las pilas, variando en el ornato desarrollado para su mayor decencia. Así, en 1673 señaló don Gonzalo de Mier y Barreda que la pila de la colegiata de San Salvador contaba con una "tapa aforrada de badana colorada, con dos llaves" ${ }^{\prime 4}$. Cabe suponer que el uso, la humedad y el deterioro propio del paso del tiempo obligasen a su renovación cada cierto tiempo, circunstancia que solía ser aprovechada para su aggiornamento estético. Así, por ejemplo, a esta misma tapadera de la pila de la colegiata ordenó el visitador don Pedro Fernández de Zurita en 1715 que "se le ponga sobreguarda nueva de damasco de color rosado con cuchillejo de oro y floqueada en redondo con flueco de seda" ${ }^{\prime 7}$. Por poner otro ejemplo con el que abundar en este particular, valga el de la pila de San Dionisio, que en 1705 contaba "con su tapa de madera y llave forrada en tela blanca y ensima otra cubierta de badana" y respecto de la cual, en 1763, el doctor José Fernando de Lora, como visitador general del arzobispado, solicitó al mayordomo "que forre la tapa de su pila con vadanas encarnadas y clavasón de metal con su senefa de damasco blanco de una tercia de ancho, para que esté con la debida desencia", abundando de este modo en las razones de decoro siempre presentes en todo cuanto en la Iglesia tenía relación con el culto ${ }^{48}$.

\footnotetext{
${ }^{45}$ De hecho, desde 1705 se debía de estar prevenido al respecto, dado que en dicho año entraron en vigor las nuevas normas dadas por el cardenal Arias a los visitadores, entre las que se insta a éstos a comprobar "si se renueva el agua (demás de las bendiciones que se hacen en el Sábado Santo y Vigilia de Pentecostés) cuando se experimenta que se corrompe". M. ARIAS y PORRES, Instrucción para los visitadores del arzobispado, Sevilla, 1705, p. 3.

${ }^{46}$ AGAS, Sección II, Serie visitas, Legajo 1443, s/fol.

${ }^{47}$ Ibídem, Legajo 1359, fol. 2r.

${ }^{48}$ Ibídem, Legajo 1348, fols. 24r.-28r. y 1396, s/fol.
} 


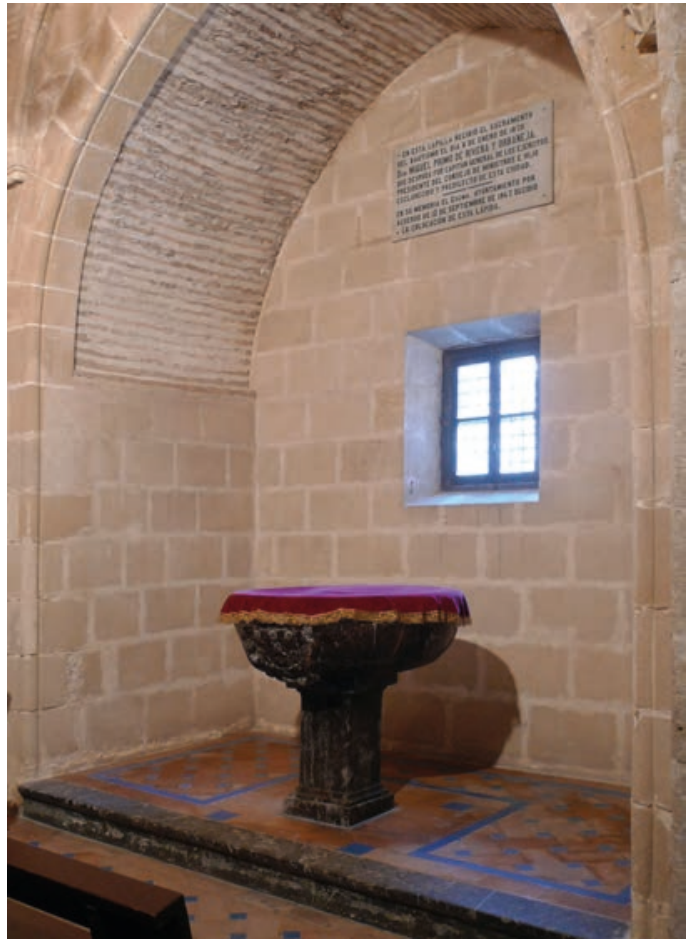

- Fig. 8. Pila bautismal. S. XVII. Parroquia de San Dionisio. Foto del autor.

Otro aspecto que incidía en la conservación del agua era el destino de la que resbalaba por la cabeza del niño que se bautizaba. El ritual preveía la existencia de una especie de escudilla donde este agua se recogiese y luego se echase a la piscina ${ }^{49}$. Una vez más podemos recurrir a las indicaciones del sínodo malagueño de Fray Alonso de Santo Tomás para entender la importancia práctica del asunto, pues se dispondrá en el mismo que "el agua con que el nuevo christiano se ha baptizado, y tocado en la cabeça, no ha de mezclarse con la demás de la pila, con la contingencia de que vaya menos pura, y mezclado con alguna indecencia o humor de cabeça del que se baptiza, sino recogerse en algún vaso donde cayga, que con asseo esté prevenido para ello, y de allí echarla en la piscina, que ha de aver junto a la pila"50. Parece que además no sólo la corruptibilidad del agua estaba en juego, sino incluso la salud de los

49 "Pelvis, seu bacile ad excipiendam aquam ex capite defluentem, nisi statim in sacrarium defluat". Rituale Romanum..., pp. 9-10.

${ }^{50}$ F. A. de SANTO TOMÁS, Op. cit., p. 274. niños que recibían el bautismo. Así, el arzobispo de Valencia don Isidoro Aliaga en sus Advertencias de 1631 insistía en la importancia de que el agua bautismal utilizada no revertiese de nuevo en la pila de donde se tomó después de haber pasado por la cabeza del niño, "que suele no estar limpia, y aun muchas vezes enferma; con lo qual, además de la indecencia, puede ser de inconveniente para los que se bautizaren después" ${ }^{51}$. En muchos lugares el recipiente que evitaría estos inconvenientes era sostenido por un monaguillo que asistía durante la ceremonia; a pesar de lo cual, pronto se vio la utilidad de que estuviese encastrado en la propia pila (Fig. 9), formando parte de la misma de manera que el sacerdote pudiera realizar la infusión del bautizando de manera más descuidada, sin tener que estar al albur de la pericia del acólito para que no se mezclasen las aguas ${ }^{52}$. Así consta que estaba, por la visita tantas veces citada de don Gonzalo de Mier en 1673, al menos en San Mateo, donde la pila tenía "dentro un casco de barro vidriado que está unido y embutido" y también en San Juan de los Caballeros, donde se describen idéntica disposición y materiales ${ }^{53}$. Seguramente otras también contarían con este recipiente integrado aunque no lo refieran los visitadores; sin embargo, a finales del XVII las de la colegiata de San Salvador, San Miguel y San Dionisio aún carecían de él, como se colige de los mandatos que dejó en estas iglesias el arzobispo Palafox tras visitarlas en 1691: "que se ponga una taza de piedra en medio

${ }^{51}$ I. ALIAGA, Advertencias para los edificios y fábricas de los templos y para diversas cosas de las que en ellos sirven al culto divino y a otros ministerios, Valencia, 1631, p. 128.

${ }^{52}$ San Carlos Borromeo en sus famosas instrucciones para la fábrica y su ajuar ya señala la forma que había de tener el mismo: "Praeter ea iusdem vasis medio alterum etiam vas marmoreum itidem forma simili at amplitudine minori; ita ut per diametrum cubito uno et unciis octo cum ipsius vasis crassitudine late patens statuatur. Idque vas sustentetur aliquo marmoreo lapideove fulcimento quod in vase inferiori nitatur. Hocque ipso in vase minori baptisrmatis aqua asservitur". C. BORROMEO, Instructionum fabricae ecclesiasticae et supellectilis ecclesiasticae [1577], Tarragona, 1859, p. 108.

${ }^{53}$ AGAS, Sección II, Serie visitas, Legajo 1443, s/fol. 


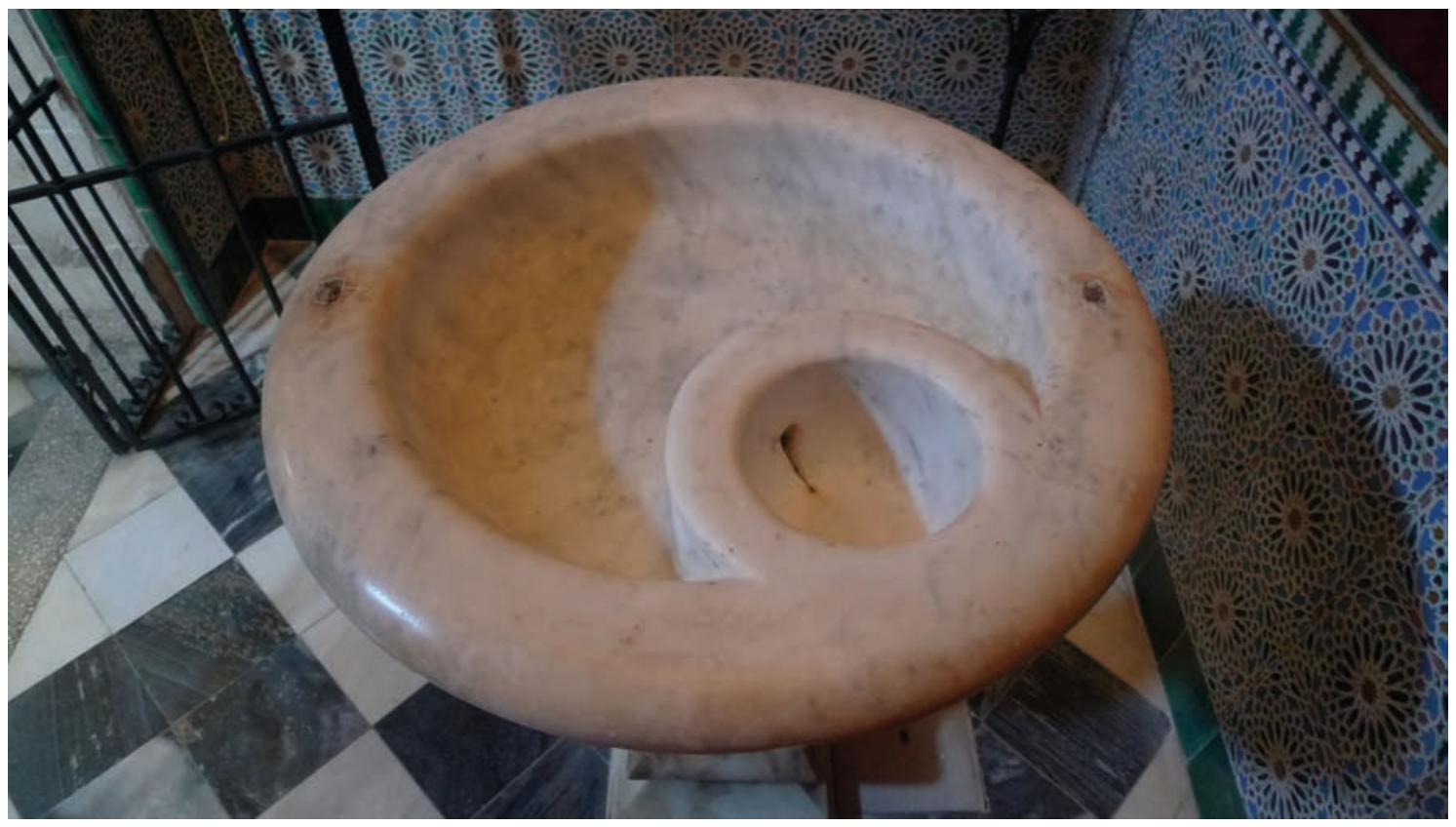

- Fig. 9. Pila bautismal de la Parroquia de San Juan de los Caballeros (Pormenor). Foto del autor.

de la pila bautismal", señalando en el caso de la colegiata que estaba pendiente el cumplimiento de un mandato dado al respecto en visita precedente ${ }^{54}$.

Tanto para el vaciado de la pila bautismal como para el del recipiente donde caía el agua de la cabeza del neófito, existían conductos que desaguaban en la piscina. Algunas, como la de San Miguel, disponían además de un sumidero adicional al pie, donde se vertía el agua de la escudilla cuando ésta era todavía de mano. Como parece evidente, para evitar tanto la pestilencia que pudiera ascender de la piscina, como la eventual entrada desde la misma de los animalejos propios de la humedad, se mandaba que el sumidero estuviese provisto de su correspondiente tapón ${ }^{55}$. Así, encontramos en 1715

${ }^{54}$ En 1715 consta que la pila de la colegiata tenía ya una "pilita que está en medio de la pila bautismal". J. L. REPETTO BETES, Op. cit., p. 519; AGAS, Sección II. Serie visitas, Legajo 1339, fols. 53r., 56r.-57r.; y 1359, fol. 2 r.

${ }^{55}$ Aliaga, en sus advertencias valencianas de 1631 señalará al respecto que "porque en estos pozos y puestos húmedos se crían gusanos, y suelen subirse por los agujeros; para que los dichos gusanos no puedan salir y pasar a la otra pila en que se conserva el agua bendita, se ha de hazer un tapador con que dicho la petición del visitador don Pedro Fernández de Zurita a la fábrica de la colegiata para que "al cañón de la dicha pila pequeña por donde derrama la referida agua se ponga tapín de piedra, no usando el que tiene de corcha" ${ }^{26}$. También lo solicita en San Mateo, San Miguel y en San Juan de los Caballeros, donde además ordena que "a la pizina que está al pie de dicha capilla se sierre la puerta y se haga una alhazena en un lado de la capilla con puertas y llave como esta mandado en visitas antezedentes con un conducto subterráneo que corresponda al sumidor, por ser la pared de cantería y seguirse graves daños en romperla por formar dicha pizina", algo a lo que no habían sido ajenos tratados de arte sacro como el del arzobispo Aliaga ${ }^{57}$.

agujero esté tapado quando no se huviere de bautizar alguno, o limpiar las pilas, o echar por él alguna cosa". I. ALIAGA, Op. cit., p. 130.

${ }^{56}$ AGAS, Sección II, Serie visitas, Legajo 1359, fol. 2r.

${ }^{57}$ La cisterna de la piscina "se ha de hazer de manera que el agua caiga desviada y apartada del fundamento de la pared, por si el agua fuere tanta que con el tiempo pueda hazer algún daño al fundamento ya dicho". I. ALIAGA, Op. cit., p. 62. 


\section{LAS TACAS}

La celebración del bautismo requería tener disponibles las piezas de ajuar sagrado propias del rito, tales como la concha para verter el agua, el salero o las crismeras, elementos todos que se guardaban en unas tacas donde también se solían conservar los libros de bautismo, el ritual y eventualmente también alguna estola, e incluso subsidiariamente los libros de matrimonio $\mathrm{y}$ velaciones ${ }^{58}$. La naturaleza mural de estas alacenas garantizaban la seguridad de las piezas contenidas, pero al tiempo comprometían su conservación dada la elevada cota de humedad que podía concentrarse en su interior. En San Mateo, por ejemplo, consta que en 1673 la taca de la capilla bautismal ya no se usaba "por ser la capilla húmeda", conservándose en otra los óleos y libros, y estos últimos consta que incluso fueron custodiados durante algún tiempo por el propio cura en su domicilio ${ }^{59}$. A esta situación trató de darle solución el visitador don Pedro Fernández de Zurita cuando ordenó en 1715 que se construyese un cajón que fuese empotrable en la mencionada taca, y que dejase por todas partes ocho dedos libres que habrían de rellenarse de corcho como material aislante. El perímetro resultante hacia el exterior se taparía con una suerte de tapajuntas

${ }^{58}$ Fray Alonso de Santo Tomás, siempre atento a los pormenores del argumento que nos ocupa, indicaba que en la taca del baptisterio había de guardarse el vaso de plata para derramar el agua, que en la archidiócesis de Sevilla tuvo siempre forma de concha, el lienzo purificador, los santos óleos y la sal. Además, como se ha señalado, era frecuente que en las tacas se conservasen los libros de bautismo, y en ocasiones también otros, como sucedía en la Colegiata y en San Miguel, donde se sabe que en 1673 se conservaban en las tacas de sus respectivos baptisterios los libros de matrimonio y velaciones, como también se constata en San Dionisio en 1705; las estolas -suponemos que morada y blanca- que eran utilizadas para los exorcismos previos y durante el rito bautismal propiamente dicho respectivamente o el Rituale, como se pedía en San Miguel en 1715. F. A. de SANTO TOMÁS, Op. cit., p. 274; AGAS, Sección II, Serie visitas, Legajos 1443, s/fol..; 1348, fols. 24r.-28r.; y 1359, fols. $47 \mathrm{v} .-48 \mathrm{r}$.

${ }^{59}$ Ibídem, Legajos 1443, s/fol.; y 1359, fols. 206r.-206v. de madera al tiempo que las puertas habrían de llevar una rejilla de hierro "para que entre el ambiente" 60 . En San Lucas, al año siguiente dispuso el mismo visitador que la taquilla del baptisterio se forrase para combatir la humedad, pero ésta debía de constituir un problema que afectaría a toda la capilla, dado que también dispuso "que se abra una ventana en la parte que se reconociera hacer más comodidad poniéndole rexa de fierro para que por ella se comunique la luz a dicha capilla que esta muy oscura, y asimismo el aire que enjugue la mucha umidad que tiene ${ }^{\prime \prime 61}$. Por último, queda por señalar la singular existencia de dos tacas en la capilla bautismal de San Dionisio, que aparecen nombradas en el plano al que aludimos con anterioridad con el no menos singular nombre de "vestuarios", y cuyo origen podrá responder a una situación semejante a las descritas, toda vez que el visitador don José de Almoriña en 1740 ordenó que se hiciesen dos tacas nuevas por razones de humedad, una para los óleos y otra para los libros ${ }^{62}$. En cuanto a la cuestión del ornato requerido a estos armarios, especialmente por conservar las crismeras con el santo crisma y el óleo de los catecúmenos, no hemos podido constatar en los ejemplos analizados la división interior de que se habla en otras diócesis ${ }^{63}$. Sin embargo, un mandato de 1715 del visitador Fernández de Zurita, que mandaba colocar una cortina de seda morada en la parte interior de la taca donde se guardaban los óleos en el baptisterio de la colegiata, parece poner

60 "que respecto a ser dicha capilla mui ancha i capaz dentro de un mes se haga una caxa de madera que aparte por todos los ocho dedos y el asiento levante otros tantos. Y que estos huecos se llenen de corchas tapandolos por la parte anterior con listones de madera y en las puertas de dicho archivo o taquilla se aga en cada una una rotura de un palmo en quadro con rexuelas de fierro para que entre el ambiente". Ibídem, Legajo 1359, fols. 206r.-206v.

${ }^{61}$ Ibídem, Legajo 1359, fols. 206r.-206v.

62 También dos tacas llegó a tener la capilla de San Juan de los Caballeros, si bien en la actualidad sólo conserva una de ellas. Ibídem, Legajo 1385, s/fol.

${ }^{63}$ I. ALIAGA, Op. cit., pp. 132-133. 
de manifiesto que también en la Archidiócesis de Sevilla se atendía, como por otra parte era previsible, a estas cuestiones de decoro ${ }^{64}$.

\section{ICONOGRAFÍA BAUTISMAL}

Como parte del mobiliario de las capillas bautismales ya nos referimos a los altares que marcaban la orientación de la ceremonia y en especial al de Nuestra Señora de la Candelaria del baptisterio de San Dionisio. También podríamos traer a colación el programa supuestamente trazado en el siglo XVIII por el beneficiado parroquial de San Lucas, don Juan González de Silva, para el baptisterio de su templo, formado por pinturas de pequeño formato que representan la fuente bautismal y las crismeras entre escenas tomadas del libro de los Hechos de los Apóstoles, como la misión de Felipe, los bautismos de San Pablo y el eunuco etíope o San Pedro predicando antes de bautizar a una muchedumbre ${ }^{65}$. Sin embargo, la iconografía que siempre había de estar presente en estas capillas era la de San Juan Bautista bautizando a Cristo $^{66}$. La pila de la antigua catedral de Sevilla, de cuya ubicación ya nos ocupamos, tenía enfrente el altar de San Juan Bautista, y así sucedería también en la nueva fábrica gótica y hasta en la nueva ubicación que mantiene desde el siglo XVII en la capilla de San Antonio, donde en el ático del retablo dedicado al titular se introdujo una pintura de Murillo representando el bautismo de $\mathrm{Cristo}^{67}$. Podemos aludir aquí una vez

64 "En la taquilla donde se guardan los Santos óleos por la parte interior se ponga una cortina nueba de seda de color morado". AGAS, Sección II, Serie visitas, Legajo 1359, fol. 2r.

65 J. M. MORENO ARANA, "La transformación barroca...", p. 110.

66 De hecho, san Carlos Borromeo, recogiendo la tradición mantenida en Italia de los baptisterios exentos, que eran una iglesia en sí mismos, señalaba que debían dedicarse a San Juan Bautista y contar con altar consagrado a este santo. C. BORROMEO, Op. cit., pp. 91-93.

67 F. HALCÓN ÁlVAREZ-OSSORIO, F. J. HERRERA GARCÍA, y Á. RECIO MIR, El retablo barroco sevillano, Sevilla, 2000, p. 241. más al Rituale Romanum de 1614, que compiló sintéticamente la tradición que ya san Carlos Borromeo había dejado recogida en sus autorizadas Instructiones, obra preñada de meticulosidad y celo contrarreformista, que prescribía que en las capillas que sirviesen de baptisterio hubiese un altar donde se representase el bautismo de Cristo en el río Jordán, pero que si por la estrechez del lugar no fuese posible, que al menos tuviesen una imagen o pintura reproduciendo la mencionada escena ${ }^{68}$. Sería el caso de muchas de las iglesias de Jerez que nos ocupan, donde hemos podido documentar su existencia probablemente estuviese en todas- así como el interés por parte de los visitadores en su restauración o sustitución si el deterioro de la obra, dada su alta capacidad pedagógica, así lo aconsejaba. De este modo, el arzobispo don Jaime de Palafox ordenó en la iglesia de San Juan de Letrán, en 1691, “que en el testero de la dicha capilla se pinte en la pared o en lienzo el baptismo de San Juan" ${ }^{\prime 69}$. Así mismo, don Pedro Fernández de Zurita estableció en 1715 en las parroquias de San Mateo, San Juan de los caballeros y Santiago que se pusiera en sus baptisterios "un quadro dezente con la pintura del bautismo del señor San Juan" y en San Marcos "que se componga la pintura del bautismo que existía en la capilla bautismal"70. De entre estas pinturas tenemos noticia de la que por man-

${ }^{68}$ El Ritual romano solicitaba que "ubi commode fieri potest, depingatur seu collocetur imago sancti Joannis Christum baptizantis", lo cual, como queda dicho, ya había sido solicitado por Borromeo en sus Instrucciones: "Altare unum tantum in hoc sacello exaedificandum est, cubitis duobus a pariete ad orientem versus extructo distans, si modo amplitudo sacelli tantum spatii ferat; forma autem reliquorum altarium et modo praefinito fiat, muniatur, saepiatur, instruatur atque ornetur. Super quo item altari in pariete expressa sit sacra historia sancti Ioannis Baptistae, Christum Dominum baptizantis. Si vero ne altare quidem praefinita amplitudine et ratione extrui ullo modo potest, illius saltem loco sit icona, aut pictura sacra, in pariete expressa, sancti Ioannis item Baptistae". Rituale Romanum..., p. 8; C. BORROMEO, Op. cit., pp. 92-93.

\footnotetext{
${ }^{69}$ AGAS, Sección II, Serie visitas, Legajo 1339, fol. $60 \mathrm{v}$.

${ }^{70}$ Ibídem, Legajo 1359, fols. 115r., 206r.-206v. y 245v.
} 
dato del visitador ejecutó el pintor mercedario fray Tomás de Palma para la parroquia de Santiago hacia $1790^{71}$. Anteriores parecen los cuadros que se conservan en el baptisterio de San Miguel, obra del siglo XVIII basada en una estampa de Cornelius Cort ${ }^{72}$; y en el de San Mateo (Fig. 10), que fue adquirido en 1788, año en que se realizaría también el retablístico marco en que se expone ${ }^{73}$.

\section{LA REJA}

El Ritual exigía que la pila del baptisterio contase con rejas -"cancellis circumseptum"- que asegurasen su inaccesibilidad ${ }^{74}$. Sin duda, como en tantos otros aspectos, se limitaba a dar forma de ley a la práctica existente, pues como vimos en 1488 aparecían ya mencionadas unas "rejas de fierro" en el baptisterio de la colegiata ${ }^{75}$. Al respecto, conviene también recordar que la pila de la catedral de Sevilla estaba rodeada de una baranda que la circundaba; así pudo ser que sucediese inicialmente en las parroquias jerezanas mientras su desarrollo arquitectónico se encontraba en ciernes y no existía en ellas capillas destinadas a baptisterio ${ }^{76}$. De este tipo debieron de ser, según los testimonios de los visitadores, las que protegían la pila de la capilla de San Juan de Letrán, dado que se habla en 1673 de un "enrejado donde está la pila" y en 1705 se indica que a esta "la cerca una reja de palo con sus puertas y llave", lo que se reitera cuatro años más tarde

${ }^{71}$ H. SANCHO DE SOPRANIS, "Papeletas para una serie de artistas regionales (segunda serie)", Guión, no 27, 1936, p. 7.

${ }^{72}$ M. Á. MARISCAL RODRÍGUEZ, y P. J. POMAR RODIL, Op. cit., p. 196.

${ }^{73} \mathrm{~J}$. M. MORENO ARANA, "Retablos y esculturas barrocos de la iglesia de San Mateo", en J. E. JIMÉNEZ LÓPEZ DE EGUILETA (coord.), La parroquia de San Mateo de Jerez de la Frontera. Historia, arte y arquitectura. Murcia, 2017, p. 487.

${ }^{74}$ Rituale Romanum..., p. 8.

75 AHDJF, Fondo Colegial, Sección II, Caja 21, Documento 44/2, fols. 2v.-25v. Vid. nota no 18 .

${ }^{76}$ A. JIMÉNEZ MARTÍN e I. PÉREZ PEÑARANDA, Op. cit., p. 115.

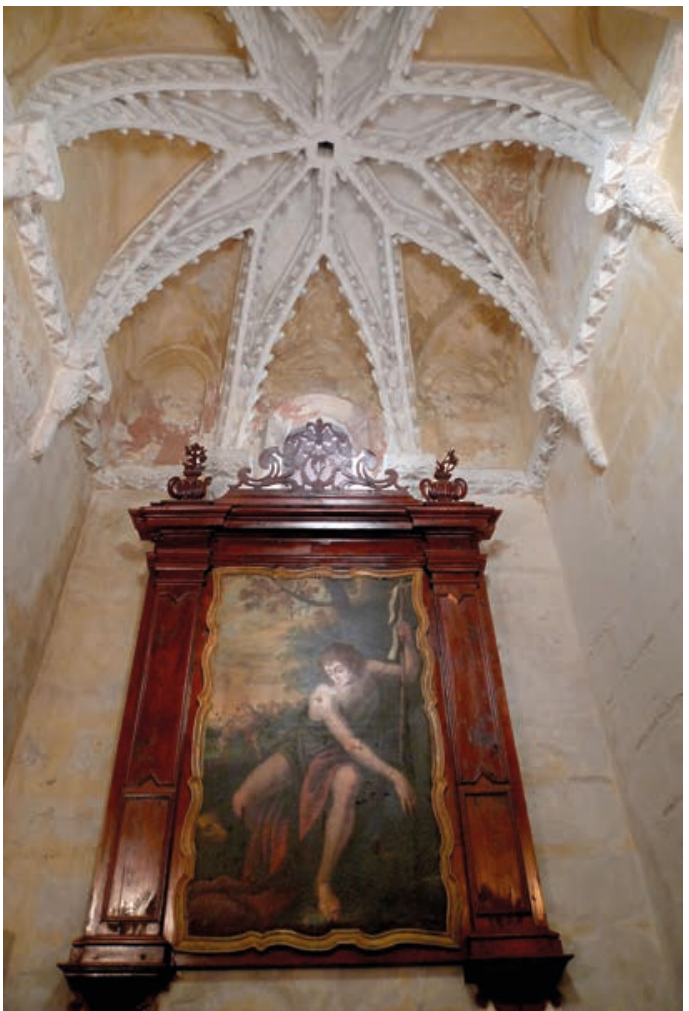

- Fig. 10. San Juan Bautista y Bautismo de Cristo. 1788. Baptisterio de la Parroquia de San Mateo. Foto del autor.

en una nueva descripción que señala cómo la pila está "dentro de unas rexas de madera de suerte que tiene la guarda nezesaria" ${ }^{77}$.

Las Constituciones Sinodales del cardenal Rodrigo de Castro ordenaron en 1597 que "las pilas de baptismo estén cerradas y con buena guarda, y los curas tengan las llaves dellas; y el que no la tuviere cerrada, pague un ducado de pena para la Fábrica"78. Este decreto, que ya vimos cómo también afectaba a la cubierta de madera de las propias pilas, anticipa lo que al respecto dispondría el Ritual algunos años más tarde. Las constituciones malagueñas de 1671 ya citadas, que por su minuciosidad se detienen en corolarios particularmente caros a nuestros fines, explican que los baptisterios necesitaban estar cerrados con reja "para que se prohíba la entrada a otra cosa que a la administra-

77 AGAS, Sección II, Serie visitas, Legajos 1443, s/ fol.; 1348, s/fol.; y 1350, s/fol.

\footnotetext{
${ }^{78}$ Constituciones del Arzobispado de Sevilla..., T. II, p. 58.
} 
ción deste Sacramento"79. En Jerez, aparte del caso de la iglesia de San Juan de Letrán, ya analizado, el resto de capillas bautismales de las parroquias contaban con rejas y cerraduras cuya llave estaba en posesión de los curas de la parroquia ${ }^{80}$. Al ser la mayor parte de las mismas de madera, estaban necesitadas constantemente de reparos y sustituciones, como se constata por ejemplo en San Dionisio, donde en 1763 el visitador José Fernando de Lora ordenó hacer nueva la reja de madera del baptisterio, que ya había sido mandada reparar en 1715 por Pedro Fernández de Zurita ${ }^{81}$. Ese mismo año también solicitó Zurita en San Miguel "que las puertas de la capilla del baptismo desde luego se reparen", como también ordenó al año siguiente en San Lucas que "se aderesen las puertas de dicha capilla [del bautismo] de lo que nezesitan para su guarda y seguridad"82. Esto haría que a lo largo del siglo XVIII muchas de estas rejas se fuesen paulatinamente sustituyendo por otras de hierro, como así consta en San Mateo ya en 1705, y como ordenó el mencionado visitador Fernández de Zurita en 1715 que se hiciese en San Miguel en el plazo de un año ${ }^{83}$. Con posterioridad sabemos que también se sustituyeron las de San Lucas, en 1728, que han sido atribuidas a Pedro Guerrero; y las de San Juan de los Caballeros, cuyos batientes fueron reprodu-

${ }^{79}$ F. A. de SANTO TOMÁS, Op. cit., p. 274.

${ }^{80}$ En la parroquia de San Miguel, el visitador don Pedro Fernández de Zurita ordenó en 1715 que a las puertas de la reja del baptisterio "se les ponga cerradura y se hagan tres llaves de yguales guardas y tenga una cada uno de los curas para abrir y cerrar quando se le ofresca estando siempre cerradas dichas puertas". AGAS, Sección II, Serie visitas, Legajo 1359, fols. 47v.48 r.

${ }^{81}$ Ibídem, Legajos 1359, fol. 153v. y 1396, s/fol.

${ }^{82}$ Ibídem, Legajo 1359, fols. 47v.-48r, y 227r.

${ }^{83}$ En la resulta de visita de Juan Bejarano Muñoz a San Mateo en 1705 se señala que la capilla del bautismo "no tiene altar, pero sí puertas de fierro con llave". En los mandatos de visita de 1715 a San Miguel, el visitador Pedro Fernández de Zurita dejó recogido que "dentro de un año dichas puertas [del baptisterio] se hagan de fierro". Ibídem, Legajos 1348, s/fol.; y 1359, fols. 47v.-48r.

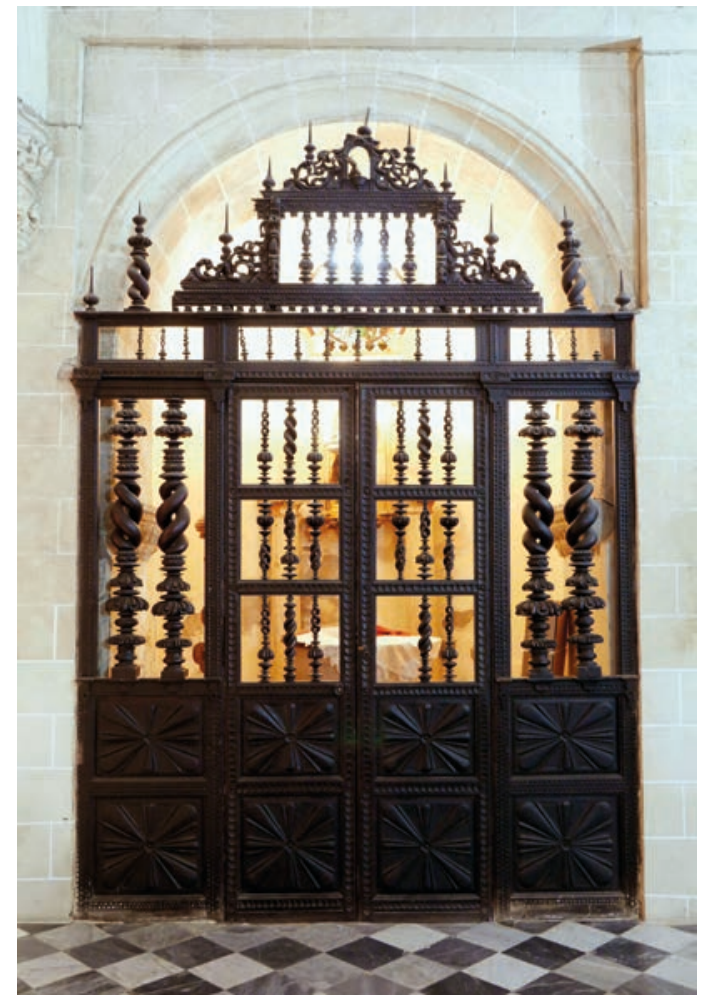

- Fig. 11. Reja del baptisterio de la Parroquia de San Marcos. ca. 1770. Foto del autor.

cidos recientemente al haber sido sustraídos los originales en la década de $1980^{84}$. Así mismo el acotamiento en forma de capilla de la nave exterior de la nueva colegiata también se hizo de hierro, tal como permaneció hasta finales del siglo XX en que el baptisterio, ya catedralicio, fue impunemente desmantelado ${ }^{85}$. Sin embargo, algunas continuaron realizándose en madera, como será el caso de la interesantísima reja torneada con balaustres de doble helicoide calado de la capilla bautismal de San Marcos (Fig. 11), que fue costeada hacia 1770 por el ilustre feligrés don José de Villavicencio ${ }^{86}$. La de San Mateo, fabricada al finalizar el siglo, parece en cierto modo emulación de aquella, si bien carece

${ }^{84}$ J. M. MORENO ARANA, "La transformación barroca...", p. 123; AGAS, Sección IV, Serie 13, Legajo $1421, \mathrm{~s} / \mathrm{fol}$.

${ }^{85}$ M. Á. ÁLVAREZ LUNA, J. M. GUERRERO VEGA y M. ROMERO BEJARANO, Op. cit., pp. 37-39.

${ }^{86} \mathrm{~J}$. M. MORENO ARANA, El retablo..., p. 475. 
de la pequeña campanilla que remata la de San $\mathrm{Marcos}^{87}$.

\section{UN MODELO DE ESTUDIO}

Los diferentes estudios que desde hace ya algunos años han reivindicado la razón litúrgica como elemento de interpretación de la arquitectura religiosa, se han apuntalado sobre los andamiajes que levantaron las grandes catedrales europeas ${ }^{88}$. Estos trabajos han demostrado que la funcionalidad litúrgica ha sido un mecanismo de capital importancia en la génesis y progreso de la arquitectura religiosa, al tiempo que también han puesto de manifiesto cómo soluciones arquitectónicas consolidadas condicionaron en no pocas ocasiones la implantación de novedades cultuales. A pesar de ello, cuando el especialista accede a estos estudios, recibe la impresión de encontrarse ante una metodología de trabajo que no sería aplicable a centros artísticos menores, a simples parroquias de poblaciones medias o incluso realidades rurales en las que tan sólo un fenómeno de imitación de la catedral, de la que esas iglesias serían meras secuelas, habría explicado la existencia de comportamientos análogos. Incluso si en algunos de estos casos no se tratase de mera emulación y se sospechase que el cumplimiento de unas rúbricas concretas o la aplicación de un ceremonial determinado pudiese probar adecuadamente una particular topografía espacial u otro tipo de elección, la escasez de fuentes que así lo hubiesen podido avalar exigirían del historiador una actuación marcada por la cautela.

Sin embargo, el ámbito y demás aspectos materiales del sacramento del bautismo que aquí hemos elegido como muestra revelan cómo las visitas pastorales aportan un

${ }^{87} \mathrm{~F}$. AROCA VICENTI, “La parroquia y el barrio de San Mateo en el siglo XVIII", en J. E. JIMÉNEZ LÓPEZ DE EGUILETA (coord.), Op.cit., p. 435.

88 Nos referimos a los luminosos trabajos de historiadores como Kees van der Ploeg, Eric Palazzo, Sible de Blaauw, Paolo Piva o Justin Kroesen y, en el ámbito hispano, a los de Isidro Bango Torviso o Eduardo Carrero Santamaría principalmente. caudal de noticias de primer orden para llevar a cabo estudios histórico-artísticos bajo el enfoque de su funcionalidad litúrgica, al conocerse tantas veces a través de sus resultas y mandatos no sólo el testimonio positivo de la datación o la autoría de una obra de arte sacro, sino la razón última que movía a su creación, tal como con frecuencia sucede en las propuestas y debates asentados en las actas de los capítulos de canónigos, que son las que han hecho posible, junto con los libros catedralicios de costumbres litúrgicas, la ya amplia producción historiográfica sobre liturgia y arquitectura a que hicimos referencia. La visita pastoral, ya vieja conocida del historiador, que con frecuencia ha hecho uso de ella desde planteamientos más convencionales y formalistas, permite conocer, por lo que dice y por lo que calla, por lo que ordena una y otra vez sin obtener obediencia y por estar al mismo tiempo en el origen de tantas novedades, la recepción local de todo el marco teórico generado a partir del Concilio de Trento entre los libros litúrgicos romanos, tratadistas como Borromeo, los sínodos diocesanos y la iniciativa episcopal ${ }^{89}$. La interpretación de la información recogida en las visitas a la luz de todas esas fuentes eclesiásticas, permite trazar, como aquí hemos hecho con los baptisterios jerezanos, distintos estudios particulares de esta cuestión capital que es la relación entre liturgia, arquitectura y artes plásticas.

${ }^{89}$ El Concilio de Trento fortaleció la autoridad de los prelados, que eran exhortados a efectuar la visita pastoral a todas las iglesias que les estaban sujetas. La visita constituía un acto sacramental, magisterial y pastoral en el cual el ordinario -o en su defecto un visitador por delegación de éste- realizaba el escrutinio de vita et moribus tanto del pueblo como del clero, controlaba la economía de las fábricas y atendía las necesidades materiales de los templos dependientes de su jurisdicción. Concilio de Trento, sesión XXIV, cap. 3, De Reformatione; I. MIGUEL GARCÍA, "El obispo y la práctica de la visita pastoral en el marco de la Teología Reformista", Memoria Ecclesiæ, no 14, 1999, pp. 347-404; R. M. PÉREZ GARCÍA, “Visita Pastoral y Contrarreforma en la Archidiócesis de Sevilla, 16001650", Historia. Instituciones. Documentos, nº 27, 2000, pp. 205-233. 


\section{BIBLIOGRAFÍA}

ALIAGA, I., Advertencias para los edificios y fábricas de los templos y para diversas cosas de las que en ellos sirven al culto divino y a otros ministerios, Valencia, 1631.

ÁlVAREZ LUNA, M. Á., GUERRERO VEGA, J. M. Y ROMERO BEJARANO, M., La intervención en el patrimonio. El caso de las iglesias jerezanas (1850- 2000), Jerez de la Frontera, 2003.

ARIAS y PORRES, M., Instrucción para los visitadores del arzobispado, Sevilla, 1705.

AROCA VICENTI, F., Arquitectura y Urbanismo en el Jerez del siglo XVIII, Jerez de la Frontera, 2002.

"La parroquia y el barrio de San Mateo en el siglo XVIII", en J. E. JIMÉNEZ LÓPEZ DE EGUILETA (coord.), La parroquia de San Mateo de Jerez de la Frontera. Historia, arte y arquitectura. Murcia, 2017, pp. 395-436.

BLAAUW, S. de, "Innovazioni nello spazio di culto fra basso Medioevo e cinquecento: La perdita dell'orientamento liturgico e la liberazione della navata", en J. STABENOW (coord.), Lo spazio e il culto. Relazioni tra edificio eclesiales e uso liturgico dal XV al XVI secolo, Venezia, 2006, pp. 25-51.

BORROMEO, C., Instructionum fabricae ecclesiasticae et supellectilis ecclesiasticae [1577], Tarragona, 1859.

Canones, et decreta sacrosanti oecumenici et generalis concilii tridentini, sub Paulo III, Iulio III, Pio IIII, pontificibus max., Alcalá de Henares, 1564.

Constituciones del Arzobispado de Sevilla hechas y ordenadas por el Ilustrísimo y Reverendísimo Sr. D. Fernando Niño de Guevara, Cardenal y Arzobispo de la Santa Iglesia de Sevilla, en el Sínodo que celebró en su Catedral año de 1604; y mandadas imprimir por el Deán y Cabildo, Canónigos in Sacris, Sede vacante, en Sevilla, año de 1609, Sevilla, 1864.
ESTEVE GUERRERO, M., Jerez de la Frontera (Guía oficial de arte), Jerez de la Frontera, 1933.

GESTOSO y PÉREZ, J., Historia de los barros vidriados sevillanos desde sus orígenes hasta nuestros días, Sevilla, 1903.

HALCÓN ÁLVAREZ-OSSORIO, F., HERRERA GARCÍA, F. J. y RECIO MIR, Á., El retablo barroco sevillano, Sevilla, 2000.

HERNÁNDEZ GONZÁLEZ, S., “Virgen con el Niño", en J.E. JIMÉNEZ LÓPEZ DE EGUILETA y P. J. POMAR RODIL (coords.), Limes Fidei. 750 años de Cristianismo en Jerez, Jerez de la Frontera, 2014, pp. 288-289.

HIDALGO SÁNCHEZ, S., "Una iconografía funeraria en la capilla Barbazana: La Virgen de la Candelaria", Cuadernos de la Cátedra de Patrimonio y Arte Navarro, no 1, 2006, pp. 63-74.

JIMÉNEZ LÓPEZ DE EGUILETA, J. E., “Libro de Bautismos (1487-1507)", en J. E. JIMÉNEZ LÓPEZ DE EGUILETA y P. J. POMAR RODIL (coords.), Limes Fidei. 750 años de Cristianismo en Jerez, Jerez de la Frontera, 2014, pp. 228-229.

JIMÉNEZ LÓPEZ DE EGUILETA, J. E. y POMAR RODIL, P. J., "La colegiata medieval de San Salvador de Jerez de la Frontera", en 750 aniversario de la incorporación de Jerez a la Corona de Castilla: 1264-2014, Jerez de la Frontera, 2014, pp. 459-484.

JIMÉNEZ MARTÍN, A. y PÉREZ PEÑARANDA, I., Cartografía de la Montaña hueca. Notas sobre los planos históricos de la catedral de Sevilla, Sevilla, 1997.

LAGUNA PAÚL, T., “La Aljama cristianizada. Memoria de la catedral de Santa María de Sevilla", en Metropolis Totius Hispaniae, Sevilla, pp. 41-71.

LÓPEZ VARGAS-MACHUCA, F., "Entre la tradición castellana y la herencia andalusí. La arquitectura religiosa en Jerez de la Frontera desde la conquista cristiana hasta la irrupción del tardogótico (1264-1464)", en J. E. JIMÉNEZ LÓPEZ 
DE EGUILETA y P. J. POMAR RODIL (coords.), Limes Fidei. 750 años de Cristianismo en Jerez, Jerez de la Frontera, 2014, pp. 65-99.

El edificio medieval de San Dionisio de Jerez de la Frontera, Jerez de la Frontera, 2014.

MARISCAL RODRÍGUEZ, M. A. y POMAR RODIL, P. J., Jerez. Guía artística y monumental, Madrid, 2004, p. 63.

MESA GINETE, F. de, Historia Sagrada y Política de la Muy Noble y Muy Leal Ciudad de Tarteso, Turdeto, Asta Regia, Asido Cesariana, Asidonia, Gera, Jerez Sidonia, hoy Jerez de la Frontera [1754], Jerez de la Frontera, 1888.

MIGUEL GARCÍA, I., "El obispo y la práctica de la visita pastoral en el marco de la Teología Reformista", Memoria Ecclesix, no 14, 1999, pp. 347-404.

MORALES MARTÍNEZ, A. J., Hernán Ruiz "el joven", Madrid, 1996.

MORENO ARANA, J. M., El retablo en Jerez de la Frontera durante el siglo XVIII, Sevilla, 2014.

"La transformación barroca de la iglesia de San Lucas de Jerez en el siglo XVIII", en F. PÉREZ MULET (coord.), Nuevas aportaciones a la Historia del Arte en Jerez de la Frontera y su entorno, Cádiz, 2016, pp. 105-136.

"Retablos y esculturas barrocos de la iglesia de San Mateo", en J. E. JIMÉNEZ LÓPEZ DE EGUILETA (coord.), La parroquia de San Mateo de Jerez de la Frontera. Historia, arte y arquitectura, Murcia, 2017, pp. 467-504.

PÉREZ GARCÍA, R. M., “Visita Pastoral y Contrarreforma en la Archidiócesis de
Sevilla, 1600-1650", Historia. Instituciones. Documentos, nำ27, 2000, pp. 205-233.

REPETTO BETES, J. L., Historia del Cabildo Colegial de Jerez de la Frontera. 1264-1984, Jerez de la Frontera, 1986.

Rituale Romanum Pauli V. P. M. iussu editum [1614], Roma, 1615.

ROMERO BEJARANO, M., "Del mudéjar al gótico. Arquitectura religiosa a finales del XV en Jerez", en 750 aniversario de la incorporación de Jerez a la Corona de Castilla: 1264-2014, Jerez de la Frontera, 2014, pp. 437-458.

Maestros de obras de ascendencia portuguesa en el tardogótico de la baja Andalucía, Tesis doctoral inédita defendida en la Universidad de Sevilla, 2014.

ROMERO DE TORRES, E., Catálogo monumental de la Provincia de Cádiz (1908-1909), Madrid, 1934.

SANCHO DE SOPRANIS, H., Introducción al estudio de la arquitectura en Xerez, Jerez de la Frontera, 1934.

"Papeletas para una serie de artistas regionales (segunda serie)", Guión, no 27, 1936, pp. 2-14.

"El arte mudéjar en Jerez", en Actas del I congreso de estudios árabes e islámicos, Madrid, 1964, pp. 417-421.

"La arquitectura jerezana en el siglo XVI", Archivo Hispalense, no 123, 1964, pp. 9-76.

SANTO TOMÁS, F. A. de, Constituciones synodales del Obispado de Málaga, Sevilla, 1674.

TESTINI, P., Archeologia cristiana. Nozioni generali dalle origini alla fine del sc. VI, Bari, 1980. 